\title{
Solar UV Irradiation-Induced Production of Greenhouse Gases from Plant Surfaces:
} From Leaf to Earth

\author{
Mikkelsen, Teis Nørgaard; Bruhn, Dan; Ambus, Per
}

Published in:

Progress in Botany

Link to article, DOI:

10.1007/124_2016_10

Publication date:

2016

Document Version

Peer reviewed version

Link back to DTU Orbit

Citation (APA):

Mikkelsen, T. N., Bruhn, D., \& Ambus, P. (2016). Solar UV Irradiation-Induced Production of Greenhouse Gases from Plant Surfaces: From Leaf to Earth. In Progress in Botany Springer. Progress in Botany https://doi.org/10.1007/124_2016_10

\section{General rights}

Copyright and moral rights for the publications made accessible in the public portal are retained by the authors and/or other copyright owners and it is a condition of accessing publications that users recognise and abide by the legal requirements associated with these rights.

- Users may download and print one copy of any publication from the public portal for the purpose of private study or research.

- You may not further distribute the material or use it for any profit-making activity or commercial gain

- You may freely distribute the URL identifying the publication in the public portal 


\section{Solar UV irradiation-induced production of greenhouse gases from plant 2 surfaces: From leaf to Earth}

Teis Nørgaard Mikkelsen ${ }^{1)}$, Dan Bruhn ${ }^{2)}$ and Per Ambus ${ }^{3)}$

${ }^{1)}$ Department of Environmental Engineering, Technical University of Denmark, Building 115, DK - 2800 Kgs. Lyngby, Denmark. e-mail: temi@env.dtu.dk

${ }^{2)}$ Department of Chemistry and Bioscience, Aalborg University, Fredrik Bajers Vej 7H, DK- 9220 Aalborg East, Denmark. e-mail: db@bio.aau.dk

${ }^{3)}$ Department of Geosciences and Natural Resource Management, University of Copenhagen, Øster Voldgade 10, DK-1350 Copenhagen K, Denmark. e-mail: peam@ign.ku.dk

\section{Abstract}

During the past few decades it has been documented that the ultra-violet (UV) component of natural sunlight alone or in combination with visible light can instantaneously stimulate aerobic plant production of a range of important trace gases: $\mathrm{CH}_{4}, \mathrm{CO}_{2}, \mathrm{CO}$, short-chain hydrocarbons/ non-methane volatile organic compounds (NMVOC), $\mathrm{NO}_{x}$ and $\mathrm{N}_{2} \mathrm{O}$. This gas production, near or at the plant surface, is a new discovery and is normally not included in emission budgets (e.g. by the Intergovernmental Panel on Climate Change, IPCC) due to a lack of information with respect to validation and upscaling. For $\mathrm{CH}_{4}$ it is known that the light dose controls emission under ambient and artificial light conditions, but the atmospheric gas composition and other environmental factors can influence gas production as well. Several plant components, including pectin and leaf wax, have been suggested as a precursor for $\mathrm{CH}_{4}$ production, but underlying mechanisms are not fully known. For other gases such generating processes have not been established yet and mechanisms remain hypothetical. Field measurements of UV-induced emissions of the gases under natural light conditions are scarce. Therefore, realistic upscaling to the ecosystem level is uncertain for all gases. Nevertheless, based on empirical response curves, we propose the first global upscaling of UV induced $\mathrm{N}_{2} \mathrm{O}$ and $\mathrm{CO}$ to illustrate emission ranges from a global perspective and as a contribution to an ongoing quantification process. When scaled to the global level, the UV-induced emission of $\mathrm{CO}$ by vegetation surfaces amounts to up to $22 \mathrm{Tg} \mathrm{yr}^{-1}$, which equals $11-44 \%$ of all the natural terrestrial plant sources accounted for so far. The total light-driven $\mathrm{N}_{2} \mathrm{O}$ emissions amount to $0.65-0.78 \mathrm{Tg} \mathrm{yr}^{-1}$, which equals $7-24 \%$ of the natural terrestrial source strength accounted for (range 3.3 - $9 \mathrm{Tg} \mathrm{N} \mathrm{yr}^{-1}$ ). In this review, we summarize current knowledge, based on experimental work with sunlight and artificial light, and estimate 
31 potential emission ranges and uncertainties, placing the available data into perspective. We discuss the

32 state of the art in proposed mechanisms, precursors, and environmental relationships, we consider the

33 relevance of measured emission rates, and we also suggest a range of future research topics. Furthermore

34 we propose and describe methods and techniques that can be used for future research.

35 Keywords: Atmospheric chemistry, air pollution, UV-A, UV-B, stabile isotopes techniques, $\mathrm{N}_{2} \mathrm{O}, \mathrm{CH}_{4}, \mathrm{NO}_{x}$ $36 \mathrm{NO}_{y}, \mathrm{CO}, \mathrm{CO}_{2}$, short-chain hydrocarbons, $\mathrm{NMVOC}$, upscaling, vegetation, plants 
$39 \quad 1$ Introduction

402 Light induced gases at the plant surface

412.1 Well-mixed greenhouse gases $\left(\mathrm{CO}_{2}, \mathrm{CH}_{4}\right.$ and $\left.\mathrm{N}_{2} \mathrm{O}\right)$

$42 \quad 2.2$ Short lived gases ( $\left.\mathrm{CO}, \mathrm{NO}_{\mathrm{x}}, \mathrm{NMVOC}\right)$

433 Methods \& techniques

444 Mechanisms, sources and emissions

454.1 UV-Radiation penetration through the canopy

464.2 UV-Radiation penetration through the leaf

$47 \quad 4.3$ UV-Photochemistry mechanism in and on plant surfaces

$48 \quad$ 4.3.1 Action spectra

49 4.3.2 UV-response functions

$50 \quad$ 4.3.3 Temperature interactions

$514.3 .4\left[\mathrm{O}_{2}\right]$ or O-radicals dependency

524.4 Precursors

535 Upscaling

545.1 Upscaling of methane, $\mathrm{CH}_{4}$

555.2 Upscaling of carbon monoxide, $\mathrm{CO}$

565.3 Upscaling of nitrous oxide, $\mathrm{N}_{2} \mathrm{O}$

576 Perspectives and conclusions

$58 \quad 6.1$ Realistic emission rates

$59 \quad 6.2$ Future studies

$60 \quad 6.3$ Known gas emission stimulated by UV

61 6.4. Perspectives

62 Appendix A Methods \& techniques

63 Appendix B Global drivers for $\mathrm{CO}$ and $\mathrm{N}_{2} \mathrm{O}$ contribution

64 Appendix $\mathrm{C}$ Response functions for global $\mathrm{CO}$ and $\mathrm{N}_{2} \mathrm{O}$ contribution

65

66

67 
For decades it has been recognized that sunlight plays significant roles in atmospheric chemistry and that the UV component is the driving force for tropospheric photochemical processes. For instance, UVphotolysis of ozone generates excited state oxygen atoms, which react with water vapour to constitute the primary source of hydroxyl radical $(\mathrm{OH})$. $\mathrm{OH}$ is the major component for the overall oxidising capacity of the troposphere (Isaksen et al. 2009). Lately, a number of trace gases are reported to be released by plants in instantaneous responses to UV-radiation, such as methane $\left(\mathrm{CH}_{4}\right)$ (Bruhn et al. 2007, 2009, 2012, 2014a; Röckmann et al. 2007; Vigano et al. 2007, 2008, 2009; McLeod et al. 2008; McLeod and Keppler, 2010; Messenger et al. 2009; Fraser et al. 2015), carbon monoxide (CO) (Derendorp et al. 2011a; Bruhn et al. 2013), short-chain hydrocarbons (Derendorp et al. 2011b; Fraser et al. 2015), mono-nitrogen oxides $\left(\mathrm{NO}_{x}\right.$ and $\mathrm{NO}_{y}$ ) (Hari et al. 2003; Raivonen et al. 2006, 2009) and nitrous oxide $\left(\mathrm{N}_{2} \mathrm{O}\right)$ (Bruhn et al. 2014b).

These UV-driven gas productions are in principle newly revealed terrestrial sources that remain to be considered in greenhouse gas accounting. Production of all gases stimulated by UV involves emissions at relatively low rates, and the group of gases are diverse and have different impacts and interactions with the atmosphere. However, several of the gases are potent greenhouse gases or interact with the turnover of atmospheric greenhouse gases.

We describe current knowledge of methods and techniques for measuring these gases, with a particular focus on the special requirements needed to accomplish flux measurements under controlled UVexposures and at generally very low rates. The distinction between laboratory and field measurements is addressed with respect to techniques and deductions. We also report on current understanding of the possible mechanisms and sources behind these gas productions, comment on current upscaling attempts, and present the first upscaling and quantification of UV stimulated $\mathrm{CO}$ and $\mathrm{N}_{2} \mathrm{O}$ emissions. Finally, we highlight the perspectives of the newly discovered UV stimulated gas sources with respect to research needs and impact on current research.

\section{Light induced gases at the plant surface}

Here we summarize the important features of most of the gases that are known to be formed at the plant surface during exposure to UV light. The gases can be divided into two groups: i) well-mixed greenhouse gases $\left(\mathrm{CO}_{2}, \mathrm{CH}_{4}\right.$ and $\left.\mathrm{N}_{2} \mathrm{O}\right)$, and ii) short-lived gases $\left(\mathrm{CO}, \mathrm{NO}_{x}\right.$, non-methane volatile organic compounds (NMVOC)). 
The atmospheric concentrations of the greenhouse gases carbon dioxide $\left(\mathrm{CO}_{2}\right)$, methane $\left(\mathrm{CH}_{4}\right)$, and nitrous oxide $\left(\mathrm{N}_{2} \mathrm{O}\right)$ have all increased since 1750 due to human activity. In 2011 the concentrations of these greenhouse gases were 391 ppm, 1803 ppb, and 324 ppb, and exceeded pre-industrial levels by about 40\%, $150 \%$, and $20 \%$, respectively (Table 2.1). Concentrations of $\mathrm{CO}_{2}, \mathrm{CH}_{4}$, and $\mathrm{N}_{2} \mathrm{O}$ now substantially exceed the highest concentrations recorded in ice cores during the past 800,000 years (Masson-Delmotte et al. 2013). The mean rates of increase in atmospheric concentrations over the past century are unprecedented in the last 22,000 years (IPCC, 2013). In Table 2.1 we present the Global Warming Potential (GWP) that integrates radiative forcing (RF) out to a particular time horizon, in this case 100 years. The GWP can be interpreted as an index of the total energy added to the climate system by a component in question relative to that added by $\mathrm{CO}_{2}$ (Myhre et al. 2013). There are multiple sources of all three gases, which can be divided into two main groups, anthropogenic and natural (Table 2.1). Quantification of the various source strengths from both groups remain uncertain and global budgets remain unclear (Ciais et al. 2013).

The main anthropogenic $\mathrm{CO}_{2}$ sources are burning of fossil fuels (coal, oil and gas), deforestation and production of cement (Ciais et al. 2013). The removal of anthropogenic $\mathrm{CO}_{2}$ from the atmosphere by natural processes will take a few hundred thousand years (Ciais et al. 2013). The natural $\mathrm{CO}_{2}$ sources are autotrophic and heterotrophic respiration, decomposition of plant tissues (litter and soil carbon that is released back into the atmosphere) and additional disturbance processes (e.g., natural fires). The natural source strength is 20 times higher than the anthropogenic emission, but is counterbalanced by natural $\mathrm{CO}_{2}$ uptake from the atmosphere by plant photosynthesis (Beer et al. 2010).

Massive increases in the number of domestic ruminants, natural gas extraction and use, expansion of rice paddy agriculture and establishment of urban landfills and waste dumps represent the dominant anthropogenic $\mathrm{CH}_{4}$ sources (Stocker et al. 2013). Wetlands are the dominant natural source of atmospheric $\mathrm{CH}_{4}$ (EPA 2010). During the last two decades, natural sources of $\mathrm{CH}_{4}$ have accounted for 35 to $50 \%$ of the decadal mean global emissions (Ciais et al. 2013).

The anthropogenic $\mathrm{N}_{2} \mathrm{O}$ sources are primarily agricultural, and the anthropogenic part accounts for approximately $40 \%$ of the total emission (Ciais et al. 2013). Natural sources are constituted by upland soils and riparian areas together with oceans, estuaries, and rivers (EPA 2010). Human-induced perturbations of the nitrogen cycle, in addition to interactions with $\mathrm{CO}_{2}$ sources and sinks, affect emissions of $\mathrm{N}_{2} \mathrm{O}$ both on land and from the ocean (Stocker et al. 2013). It is likely that $\mathrm{N}_{2} \mathrm{O}$ emissions from soils will increase due to 
the increased demand for feed/food and the reliance of agriculture on nitrogen fertilizers. Climate warming will likely amplify agricultural and natural terrestrial $\mathrm{N}_{2} \mathrm{O}$ sources (Ciais et al. 2013).

Table 2.1. Important features of gases that are known to be formed at the plant surface during exposure

\begin{tabular}{|l|c|c|c|c|c|c|c|c|c|c|c|}
\hline & & & \multicolumn{5}{|c|}{ Source } \\
\hline GAS & Atm. Conc. & Ref & Lifetime (years) & Ref & GWP 100 year & Ref & Antropogenic & Ref & Natural & Ref & Units \\
\hline $\mathbf{C H}_{\mathbf{4}}$ & $1803 \mathrm{ppb}$ & 3 & 9.1 & 3 & 28 & 5 & $354 \pm 45$ & 1 & $202 \pm 35$ & 1 & $\mathrm{Tg} \mathrm{CH} 4 \mathrm{yr}-1$ \\
\hline $\mathbf{C O}_{\mathbf{2}}$ & $391 \mathrm{ppm}$ & 3 & n.a. & - & 1 & 5 & $8.3 \pm 0.7$ & 1 & n.a. & 1 & $\mathrm{PgC} \mathrm{yr}-1$ \\
\hline $\mathbf{N}_{\mathbf{2}} \mathbf{O}$ & $324 \mathrm{ppb}$ & 3 & 131 & 3 & 265 & 5 & $6.9(2.7-11.1)$ & 1 & $11.0(5.4-19.6)$ & 1 & $\mathrm{TgN} \mathrm{yr}-1$ \\
\hline $\mathbf{C O}$ & $80 \mathrm{ppb}$ & 4 & months & 5 & $5.3 * * \pm 2.3$ & 7 & 608 & 1 & $50-200^{* * *}$ & 8 & $\mathrm{TgC} \mathrm{yr}-1$ \\
\hline $\mathbf{N O} \mathbf{X}_{\mathbf{X}}$ & $5-999 \mathrm{ppt}$ & 4 & hours & 3 & $-159 * * \pm 79$ & 7 & 37.5 & 2 & 11.3 & 2 & $\mathrm{TgN} \mathrm{yr}-1$ \\
\hline $\mathbf{N M V O C}$ & n.a. & - & hours - months & 3 & n.a. & - & 126.9 & 6 & $440-720^{*}$ & 6 & $\mathrm{TgC} \mathrm{yr}-1$ \\
\hline
\end{tabular}

*) Only isoprene and monoterpenes, ${ }^{* *}$ ) direct and indirect aerosol effects included, ${ }^{* * *}$ ) only from plants. et al. 2013; 6) Boucher et al. 2013, 7) Shindell et al. 2009; 8) Tarr et al. 1995

\subsection{Short lived gases $\left(\mathrm{CO}, \mathrm{NO}_{\mathrm{x}}, \mathrm{NMVOC}\right)$}

Emissions of $\mathrm{CO}, \mathrm{NMVOCs}$ and $\mathrm{NO}_{\mathrm{x}}\left(\mathrm{NO}+\mathrm{NO}_{2}\right)$ do not have a direct effect on $\mathrm{RF}$, but affect climate indirectly as precursors to tropospheric $\mathrm{O}_{3}$ and aerosol formation, and their impacts on hydroxylconcentrations and $\mathrm{CH}_{4}$ lifetime. NMVOCs include aliphatic, aromatic and oxygenated hydrocarbons (e.g., aldehydes, alcohols and organic acids), and have atmospheric lifetimes ranging from hours to months. Global coverage of NMVOC measurements is poor, except for a few compounds (Hartmann et al. 2013). Emissions of $\mathrm{CO}$ and NMVOC are virtually certain to have induced a positive RF via production of the climatic drivers $\mathrm{CO}_{2}, \mathrm{CH}_{4}$ and $\mathrm{O}_{3}$, while emissions of $\mathrm{NO}_{x}$ are likely to have induced a net negative RF. (Table2.1; IPCC, 2013). With its lifetime of 2 to 3 months, the effect of $\mathrm{CO}$ emission is less dependent on location than is the case for $\mathrm{NO}_{x}$ (Myhre et al, 2013). Due to their short atmospheric lifetime (hours), $\mathrm{NO}_{x}$ concentrations are highly variable in time and space. Solomon et al. (2007) described the potential of satellite observations of $\mathrm{NO}_{2}$ to verify and improve $\mathrm{NO}_{x}$ emission inventories and their trends, and reported $\mathrm{NO}_{2}$ increases of $50 \%$ over the industrial areas of China from 1996 to 2004. An extension of this analysis reveals increases between of 1.7x and 3.2x over parts of China, while over Europe and the USA $\mathrm{NO}_{2}$ has decreased by 30 to 50\% between 1996 and 2010 (Hilboll et al. 2013). 
The major sources of atmospheric $\mathrm{CO}$ are in situ production by oxidation of hydrocarbons $\left(\mathrm{mostly} \mathrm{CH}_{4}\right.$ and isoprene) and direct emission resulting from incomplete combustion of biomass and fossil fuels. The

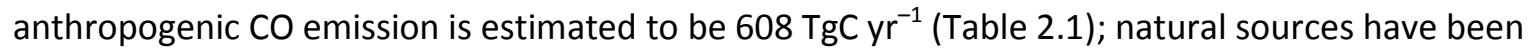
estimated to account for up to half of the global CO emissions (Khalil and Rasmussen, 1990), and direct

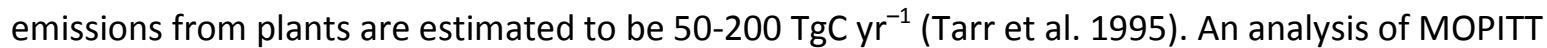
(Measurements of Pollutants in the Troposphere) and AIRS (Atmospheric Infrared Sounder) satellite data suggest a clear and consistent decline of CO columns for 2002-2010 over a number of polluted regions in Europe, North America and Asia, with a global trend of about $-1 \% \mathrm{yr}^{-1}$ (Yurganov et al. 2010; FortemsCheiney et al. 2011; Worden et al. 2013; Hartmann et al. 2013).

Reports on trends in a range of NMVOCs generally indicate a decline over urban and rural regions of North America and Europe, on the order of a few percent to more than $10 \% \mathrm{yr}^{-1}$ (Hartmann et al. 2013). The anthropogenic emission is between 15 and $22 \%$ of the total NMVOC emissions (Table 2.1)

\section{Methods \& techniques}

UV-induced gaseous emissions from specific substances, plant organs, whole plants or whole ecosystems have classically been studied under controlled environmental conditions by employment of sealed enclosures ranging in complexity from simple commercial test tubes to highly advanced plant cuvettes (plant parts) or whole chamber enclosures (plants or plant and soil communities).

Generally the studied gas components are emitted at very low rates from plant surfaces, and in order to achieve detectable levels of gas accumulation the use of enclosures is required. A static enclosure that is operated by manual sampling or connected in a closed gas sampling loop to the analyzer (e.g. Bruhn et al. 2009; 2014b) provides high analytical sensitivity for determining changes in gas mixing ratios, but may require appropriate meticulous techniques to control undesired changes in other gas components, e.g. moisture, $\mathrm{CO}_{2}$ and $\mathrm{O}_{3}$. Alternatively an open flow-through design may be used whereby the enclosure is continuously purged with ambient- or zero-air (e.g. Vigano et al. 2008). Meanwhile, deployment of enclosures is associated with multiple challenges that may affect the experimental conditions in uncontrolled and undesired directions, leading to experimental flaws and artefacts.

Environmental controls of temperature, humidity and air composition are crucial for work with biological materials in enclosures and to reveal important abiotic controllers for the investigated processes.

Complications by uncontrolled changes in the environment may further be augmented by the fact that 
relatively long enclosure times are needed in order to uncover low reaction constants. It is beyond the scope of this article to provide a detailed protocol of principles and methodologies for the use of sealed enclosures to study gas exchange from surfaces. Instead, the reader is referred to literature providing detailed descriptions on flux-chamber design and applications (e.g. de Klein and Harvey, 2015; Altimir et al. 2002; Skiba et al. 1992). In appendix A, we expand methods \& techniques with respect to temperature, chamber material, surface reactions and reactive species, analysis of gas mixing ratios and light sources.

\section{Mechanisms, sources and emissions}

Sunlight can induce trace gas emission from plants by several mechanisms from different precursors. Here we focus on direct effects of UV radiation on trace gas emission from terrestrial plant surfaces as these are largely ignored in global budgets. Indirect effects of UV on trace gas emission and other physiological functions are reviewed elsewhere (Caldwell et al. 1995, 1999; Björn et al. 1996; Rozema et al. 1997; Bruhn et al. 2012).

\subsection{UV-Radiation penetration through the canopy}

Leaves throughout a canopy are affected not only by the PAR and IR-spectrum of solar radiation but also by UV radiation. Leaves do not transmit UV radiation but reflect some (up to ca. 6\%) UV radiation (Grant 1997), and the high energy light still penetrates the canopy. Canopy structure, leaf area index (LAI), the extent of direct and diffuse radiation all influence UV penetration through the canopy (Brown et al. 1994; Shulski et al. 2004) and leaves. The penetration by UV-B varies less than that of PAR with leaf inclination due to the higher diffuse component of UV light than PAR (Caldwell 1981; Deckmyn et al 2001). For example, canopy UV-B transmittance $(\tau)$ may vary with LAI between $\tau=\exp (-1.01 \mathrm{LAI})$ and $\tau=\exp (-$ 0.17(LAl-1)) depending on species and degree of clear sky (Shulski et al. 2004).

\subsection{UV-Radiation penetration through the leaf}

UV-B absorption of adaxial leaf cuticles caused by pigments (chromophores, e.g. flavonoids and other phenolic compounds covalently bound to cutin) ranges from very high in some species with $<3 \%$ transmittance to $>64 \%$ transmittance in other species (Bauer et al. 1998). The highest absorption is typically in evergreen species (Baur et al. 1998). Some evergreen species also contain fluorophores in the cuticular wax, which may convert solar UV irradiation into blue light that can be harnessed for photosynthesis. 
214 However, the epicuticular wax per se (fatty acyl chains) can also absorb significant amounts of UV-B and thus protect against UV-B (Long et al. 2003). Further, trichome layers also protect against UV-B (Karabourniotis \& Bornman 1999). UV-A radiation penetrates deeper into the mesophyll than UV-B in all examined species (Liakoura et al. 2003). Whereas pigment changes in leaves during seasonal changes result in varying degrees of reflectance and transmittance of PAR and IR, there appear to be no seasonal changes in degrees of reflectance and transmittance in the UV region (Yoshimura et al. 2010), despite strong seasonal fluctuations in the leaf concentration of UV-absorbing compounds (Liakoura et al. 2001).

\subsection{UV-Photochemistry mechanism in and on plant surfaces}

Photochemical reactions are typically complex. UV radiation can excite various molecules and this may result in a change in molecular orbital occupancy, an increase in energy, and changes in local bonding and charge distribution. Upon return to a lower energy state of the molecules, the released energy or the energy transfer to a neighbouring molecule triggers reactions almost instantaneously. The radiation energy is inversely proportional to the wavelength. Thus, UV-B radiation causes the cleavage of more chemical bonds than does for instance UV-A and PAR. Following this, a multitude of radical reactions may take place and thus greatly increase the quantum yield. From the lab there is plenty of evidence that artificial UV radiation induces an almost instantaneous, i.e. photochemically induced, trace gas emission from plants or plant components, such as carbon-based molecules including $\mathrm{CH}_{4}$ (McLeod et al. 2008; Keppler et al. 2008; Vigano et al. 2008, 2009; Bruhn et al. 2009, 2014; Messenger et al. 2009; Fraser et al. 2015), CO (Tarr et al. 1995; Schade et al. 1999; Brandt et al. 2009; Derendorp et al. 2011a; Bruhn et al. 2013), $\mathrm{CO}_{2}$ (McLeod et al. 2008), and hydrocarbons (McLeod et al. 2008; Derendorp et al. 2011b; Fraser et al. 2015) and nitrogen-based molecules including $\mathrm{N}_{2} \mathrm{O}$ (Bruhn et al. 2014b) and $\mathrm{NO}_{x} / \mathrm{NO}_{y}$ (Hari et al. 2003; Raivonen et al. 2006, 2009). Conversely, from the field distinct evidence that natural UV radiation induces an almost instantaneous, i.e. photochemically induced, trace gas emission from plants is far less common, but is documented for $\mathrm{CO}$ (Bruhn et al. 2013), $\mathrm{N}_{2} \mathrm{O}$ (Bruhn et al. 2014b) and $\mathrm{NO}_{x} / \mathrm{NO}_{y}$ (Hari et al. 2003; Raivonen et al. 2006, 2009). With respect to $\mathrm{CH}_{4}$ and isoprene, however, there are only indirect indications that natural UV radiation induces an almost instantaneous emission (Keppler et al. 2006; Tiiva et al. 2007).

\subsubsection{Action spectra} Additional evidence pointing towards direct UV-induced trace gas emission from plants or plant components being an abiotic rather than a biotic process is that in most cases the higher energy UV-B 
results in higher emission rates than does UV-A at a given irradiance intensity. This is observed in the lab for plant emission of $\mathrm{CH}_{4}$ (McLeod et al. 2008; Bruhn et al. 2009), $\mathrm{CO}$ (Tarr et al. 1995; Schade et al. 1999; Bruhn et al. 2013) and $\mathrm{N}_{2} \mathrm{O}$ (Bruhn et al. 2014b). Only McLeod et al. (2008) have conducted a detailed analysis of the action spectrum of direct UV-induced trace gas emission, finding the $\mathrm{CH}_{4}$ efflux rate from citrus pectin-impregnated glass fibre sheets to scale linearly with an idealized spectral UV weighting function. The function weighted $\mathrm{CH} 4$ efflux is an order of magnitude lower for each $80 \mathrm{~nm}$ increase in wavelength. This spectral weighting function differs from other processes where metabolic activity intrinsically is involved, such as the erythema function (see further discussion in McLeod et al. 2008).

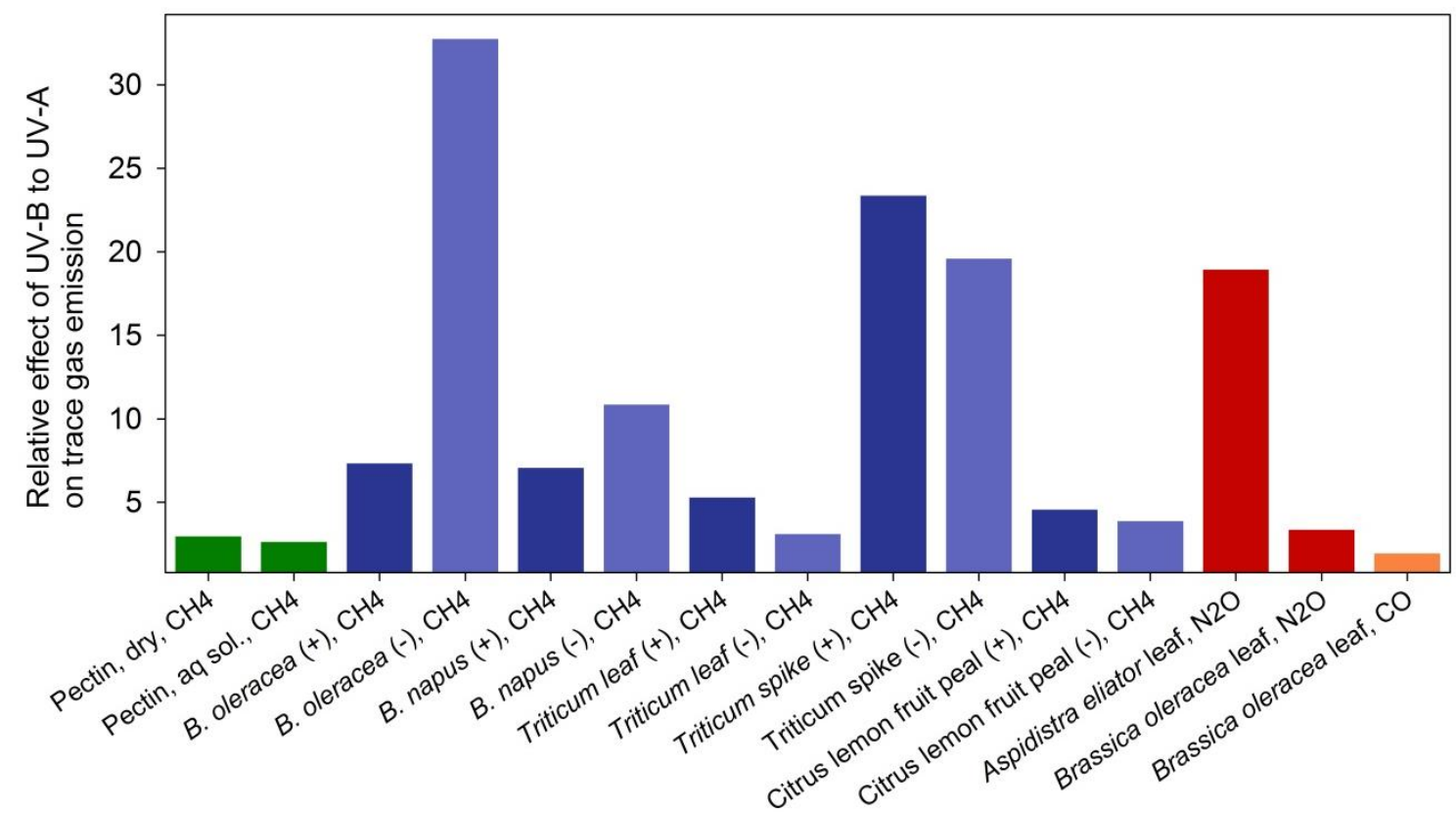

Plant components

Figure 4.1. Relative effect of UV-B to UV-A on trace gas emission from different plant components and surfaces. The relative effect of UV-B to UV-A is here defined as emission rate in response to UV-B $(312 \mathrm{~nm})$ relative to that in response to UV-A $(375 \mathrm{~nm})$ when adjusted according to irradiance intensity. $\mathrm{CH}_{4}$ : Pectin, dry (McLeod et al. 2008), Pectin, aq. sol. (Bruhn et al. 2009), Brassica oleracea leaves, Brassica napus leaves, Triticum leaves, Triticum ears, and citrus lemon fruit peal (Rolsted MMM, Bruhn D, Mikkelsen TN, Ambus P unpublished); $\mathrm{N}_{2} \mathrm{O}$ : Bruhn et al. (2014b); CO: Bruhn et al. (2013). (+) designates that natural surface wax is present, (-) designates that natural surface wax is either removed mechanically or not present at all (in the case of Triticum spikes). Green $=\mathrm{CH}_{4}$ from pectin, Dark blue $=\mathrm{CH}_{4}$ from leaf with nat. wax. Light blue $=\mathrm{CH}_{4}$ from leaf without nat. wax, Red $=\mathrm{N}_{2} \mathrm{O}$, Orange $=\mathrm{CO}$. 
The crude indication of an action spectrum of $\mathrm{CH}_{4}$ emission from pectin in aqueous solution (Fig 4.1) resembles the detailed action spectrum of citrus pectin-impregnated glass fibre sheets (Fig 4.1). Importantly, though, the crude indication of action spectra of trace gas emission appear to be highly dependent on the precursor as well as the condition of that precursor (Fig 4.1). For example leaves of two Brassica species appear to emit relatively far more $\mathrm{CH}_{4}$ in response to UV-B than to UV-A, as would be expected from the results of a single component such as pectin. Furthermore, in the case of the leaves of the two Brassica species, it appears that the removal of leaf surface wax results in a relatively higher effect of UV-B to that of UV-A in terms of $\mathrm{CH}_{4}$ emission. This may reflect a combination of UV-A radiation penetrating deeper into the mesophyll than UV-B in all examined species (Liakoura et al. 2003) when the wax is intact. However this depends on species (Baur et al. 1998) and perhaps several plant components (incl. surface wax per se) are potential precursors to UV induced trace gas emission (Table 4.1).

\subsubsection{UV-response functions}

UV induced trace gas emission is commonly reported to exhibit a near linear response function from both intact organs/tissues as well as from single plant components (McLeod et al. 2008; Bruhn et al. 2009, 2013, 2014a; Derendorp et al. 2011). This, together with the fact that direct UV induced trace gas emission often occurs at constant rates over long periods (Bruhn et al. 2009), strongly indicates photochemical reactions from plentiful precursors.

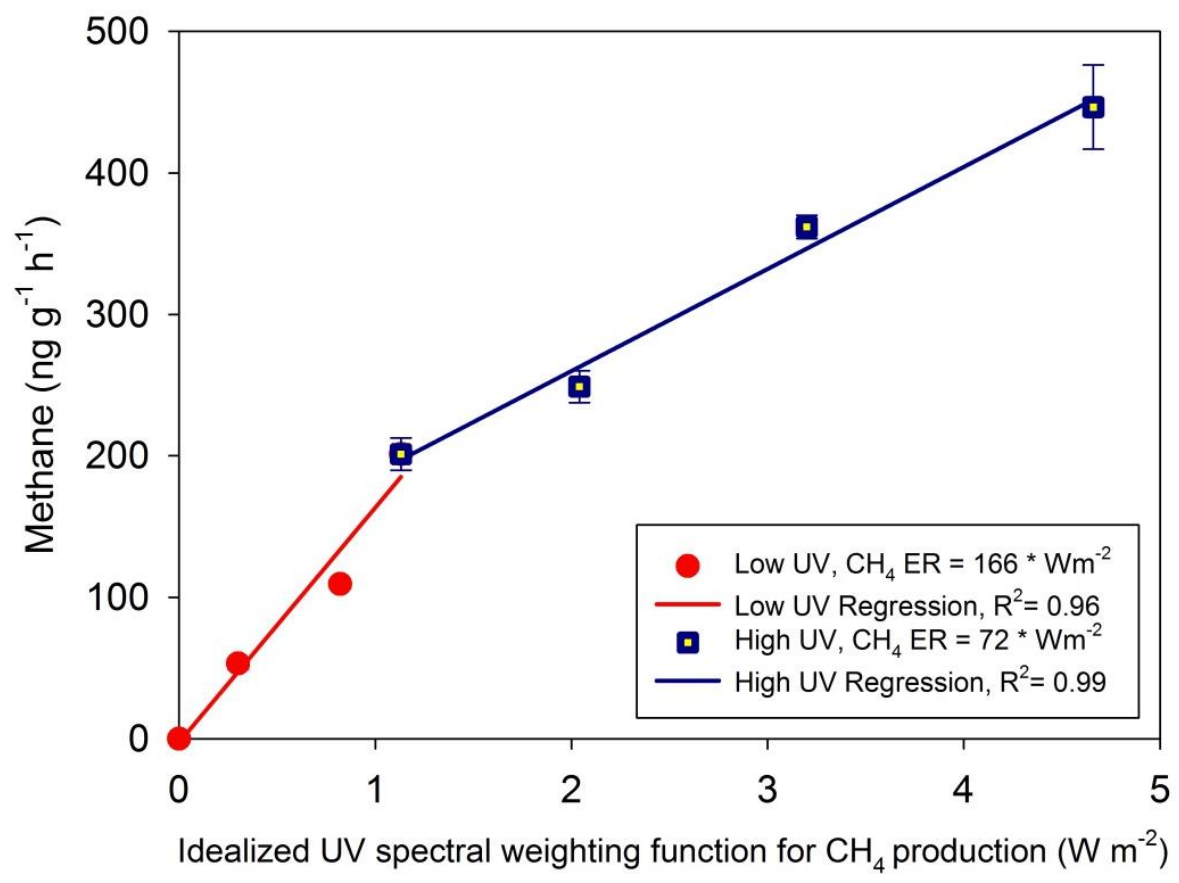

Fig. 4.2. Pectin $\mathrm{CH}_{4}$ production ( $\mathrm{ng} \mathrm{g}^{-1} \mathrm{~h}^{-1}$ ) as a function of spectrally weighted UV-intensity $\left(\mathrm{W} \mathrm{m}^{-2}\right)$. The $\mathrm{CH}_{4}$ production decays one decade when the spectrum increases $80 \mathrm{~nm}$, e.g. the $\mathrm{CH}_{4}$ emission is 1 at $300 \mathrm{~nm}$ 
and 0.1 at $380 \mathrm{~nm}$ : spectral weighting function from Fig. 1a and data from Table 1 in McLeod et al. (2008). Data is from the UV313 lamp filtered with $125-\mu \mathrm{m}$ cellulose diacetate which filters UV wavelengths $<290$ $\mathrm{nm}$. ER = Emission Rate. Linear regressions functions shown in box. Values are means of three replicates and standard errors are less than symbol size except where visible.

However, further examination (Fig. 4.2) of the only published dataset on UV-induced pectin-based $\mathrm{CH}_{4}$ productions at very low UV intensities indicates release to be more responsive (by a factor of two) than under higher intensities. The role of self-shading in this context remains to be fully investigated. Thus, even for simple linear responses in UV-induced trace gas emission, there is reason to believe that the underlying photochemical mechanisms are complex. Only Raivonen et al. (2009) have reported on an analysis of the potential linearity of the direct response function of any trace gas $\left(\mathrm{NO}_{\mathrm{x}}\right)$ emission to natural temporal variation in UV intensity (UV-A).

\subsubsection{Temperature interactions}

In most cases trace gas emission from plant material is also observed in darkness (PAR and UV absent) and with a positive response to temperature increases, although with sensitives too low to infer underlying abiotic processes (Derendorp et al. 2011a). However, reliable indications are lacking of interactions between the photochemical reactions and temperature with respect to trace gas emission from plant material.

\subsection{4 $\left[\mathrm{O}_{2}\right]$ or O-radicals dependency}

It caused quite a surprise (Kirschbaum et al. 2006, 2007) when Keppler et al. (2006) first reported an aerobic plant $\mathrm{CH}_{4}$ emission in response to solar radiation. In all examined cases of UV induced trace gas emission from plant materials, there is a positive dependency on $\left[\mathrm{O}_{2}\right]$ or O-radicals (Table 4.1). Further, this confirms a combination of instantaneous photochemical reactions and subsequent radical reactions in most cases. UV radiation can therefore in theory act as a stimulus via an increased reactive oxygen species (ROS) reaction, and consequently the actual precursor of the emitted gas does not itself need to be a good absorber of UV radiation for the process to occur. However, Lee et al. (2012) provide evidence that photooxidation may only be one of several photo degradation processes, as they observed the process occurring in the absence of $\mathrm{O}_{2}$. They speculated that the direct breakdown of chemical groups such as carboxyl, carbonyl, and methoxyl groups may result in $\mathrm{CO}_{2}, \mathrm{CO}$, and $\mathrm{CH}_{4}$ release.

\subsection{Precursors}


323 In Table 4.1 we have compiled current knowledge on the potential precursors for trace gas formation in direct response to UV radiation examined and/or suggested in the literature. For the C-based trace gases there are many structural components, which may act as precursors. In contrast, for the N-based trace gases the potential precursors appear to be more dependent on surface deposited molecules (Table 4.1).

Table 4.1 Potential precursors for trace gas formation in direct response to UV radiation examined and/or suggested in the literature.

\begin{tabular}{|c|c|c|c|c|}
\hline Gas & $\begin{array}{l}\text { Suggested source (plant or } \\
\text { surface deposit) }\end{array}$ & Ref & $\begin{array}{l}\text { Positive }\left[\mathrm{O}_{2}\right] \text { or } \mathrm{O}- \\
\text { radicals-dependence }\end{array}$ & Ref \\
\hline $\mathrm{CH}_{4}$ & $\begin{array}{l}\text { Pectin (methyl groups) } \\
\text { Wax } \\
\text { (15-nonacosanone \& 2- } \\
\text { hexadecanone) } \\
\text { Cellulose } \\
\text { Lignin } \\
\text { Methionine } \\
\text { Ascorbic acid }\end{array}$ & $\begin{array}{l}1,2,3,4,5,6,7 \\
8 \\
3,4 \\
3,4 \\
9 \\
10\end{array}$ & $\begin{array}{l}\text { Yes } \\
\text { Yes } \\
\\
? ? \\
? ? \\
? ? \\
\text { Yes }\end{array}$ & $\begin{array}{l}2,7 \\
8 \\
\\
\\
10 \\
\end{array}$ \\
\hline $\mathrm{CO}$ & Cellulose & 11 & Yes & $12,13,14$ \\
\hline $\mathrm{CO}_{2}$ & Lignin & 15,16 & & \\
\hline $\begin{array}{l}\text { C2-C5 } \\
\text { hydrocarbons }\end{array}$ & $? ?$ & 11,17 & Yes & 11 \\
\hline $\mathrm{N}_{2} \mathrm{O}$ & $\begin{array}{l}\text { Wax, } \\
\text { Mesophyll } \\
\text { Surface bound } \mathrm{N}_{2} \mathrm{O} \\
\mathrm{NO}_{3}^{-} \\
\mathrm{NH}_{4} \mathrm{NO}_{3}\end{array}$ & $\begin{array}{l}18 \\
18 \\
19 \\
20 \\
18,21\end{array}$ & Yes & $20,22,23$ \\
\hline NOx,y & $\begin{array}{l}\text { needle surfaces, } \\
\mathrm{HNO}_{3} \text { or } \mathrm{NO}_{3}^{-}\end{array}$ & $24,25,26$ & & \\
\hline
\end{tabular}

References: 1) Keppler et al. 2006; 2) Keppler et al. 2008; 3) Vigano et al. 2008; 4) Vigano et al. 2009; 5) McLeod et al. 2008; 6) Bruhn et al. 2009; 7) Messenger et al. 2009; 8) Bruhn et al. 2014a; 9) Bruhn et al. 2012; 10) Althoff et al. 2014; 11) Schade and Crutzen 1999; 12) Tarr et al. 1995; 13) Yonemura et al. 1999; 14) Derendorp et al. 2011; 15) Rozema et al. 1997; 16) Day et al. 2007; 17) Fraser et al. 2015; 18) Bruhn et al. 2014b; 19) Kim et al. 2010; 20) Rubasinghege \& Grassian, 2009; 21) Rubasinghege et al. 2011; 22) Prasad, 2002; 23) Prasad and Zipf, 2008; 24) Hari et al. 2003; 25) Raivonen et al. 2006; 26) Raivonen et al. 2009. ?? equals unknown. 
339 It seems to be the consensus that the polysaccharide pectin is the most important precursor for UV induced plant $\mathrm{CH}_{4}$ emission due to its content of methyl groups (Keppler et al. 2006, Keppler et al. 2008; Vigano et al. 2008, 2009; McLeod et al. 2008; Bruhn et al. 2009; Messenger et al. 2009; Bloom et al. 2010; Fraser et al. 2015). Whereas we agree that pectin is one of the potential precursors, we are currently not convinced that it necessarily is the most important one. Pectin is laid down in primary plant cell walls. For pectin to be reached by UV irradiation in nature, UV irradiation has to first penetrate the outer surface wax layer naturally occurring on plant organs. In Figure 4.3 we show different pairs of plant organs with natural surface wax or without surface wax, respectively.
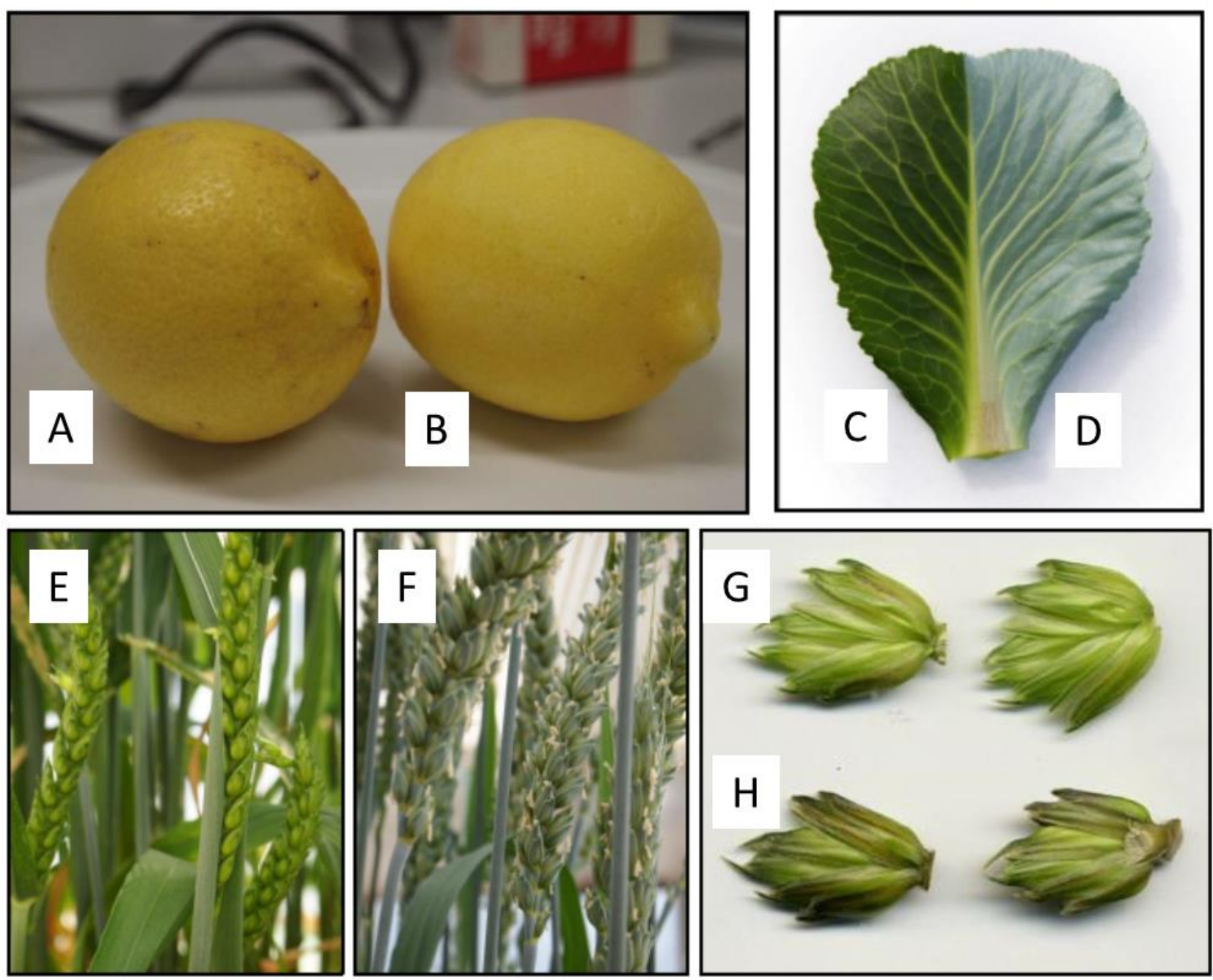

Figure 4.3. Different pairs of plant material with different amounts of surface wax. $A+B$ ) Organically grown Citrus limon fruit with natural surface wax (A) or with wax mechanically removed (B) by gentle scrubbing with a kitchen sponge. $C+D$ ) Brassica oleracea capitata $f$. alba leaf with surface wax removed (C) or intact (D). E+F) Triticum aestivum "Tähti" (E, with almost no surface wax) and Triticum aestivum "Vinjett" 

aestivum "Vinjett" (H) ears. Rolsted MMM, Bruhn D, Mikkelsen TN, Ambus P unpublished. Photos: Rolsted MMM.

As described in Section 4.2, UV irradiation is to some degree screened at the surface of plant tissues and organs. Thus, an approach to illustrate whether pectin is the most important precursor for $\mathrm{CH}_{4}$ formation is to measure and compare the UV induced $\mathrm{CH}_{4}$ production from material of pairs of plant organs with more or less natural UV-screening surface wax (Figure 4.3) as well as in samples of plant leaves with or without the natural wax removed. We did this and found that UV-B induced $\mathrm{CH}_{4}$ formation in both citrus limon peels and Cydonia oblonga peels as well as in Brassica oleracea capitata f. alba leaves was halved upon removal of the surface wax. This evidently contradicts the notion that in nature pectin is the most important precursor for UV induced $\mathrm{CH}_{4}$ formation, especially because both citrus limon peels and Cydonia oblonga peels are chosen for industrial pectin extraction due to the high pectin content. Conversely, there was no difference in UV-B induced $\mathrm{CH}_{4}$ formation between Triticum aestivum "Tähti" (with almost no surface wax) ears and Triticum aestivum "Vinjett" (with normal surface wax) ears, or between leaves of Triticum aestivum when irradiated from either adaxial side (with almost no wax) or from the abaxial side (with much natural surface wax). Removal of surface wax should, in theory, increase UV exposure of the pectin, but in no case did wax removal result in a higher rate of $\mathrm{CH}_{4}$ formation. Furthermore, we recently demonstrated that the surface wax per se is resulting in $\mathrm{CH}_{4}$ formation upon UV irradiation (Bruhn et al. 2014a). In conclusion, we are still far from having a clear understanding of the relative contribution of different precursors in any UV induced trace gas formation and emission. Additionally, given that UV radiation of different wave-lengths reaches different depths in the plant tissue (Liakoura et al. 2003) in a species- dependent manner (Bauer et al. 1998), it seems most likely that each of the different precursors (Table 4.1) are affected differently with respect to wave-lengths of UV irradiation. Consequently, we cannot with any certainty extrapolate an action spectrum for one precursor to that of an entire tissue or organ (Fig. 4.1).

\section{Upscaling}

When an unaccounted natural source is discovered there is an urgent demand for extrapolating observed rates to a global scale, so the magnitude of the new source can be put into perspective. However, if 
mechanisms are unknown, there is a high risk in an upscaling exercise, because driving forces and controlling factors unintentionally might be ignored, leading to the wrong outcome. On the other hand, if some factors are known, response curves can be constructed and upscaling can be conducted under defined premises, even though there are still unknown factors. Results can then be treated as a platform for understanding and as a contribution to an ongoing knowledge improvement process. Based on current knowledge, we suggest a simple global upscaling and source strength for sunlight-induced emission of the gases $\mathrm{CH}_{4}, \mathrm{CO}$, and $\mathrm{N}_{2} \mathrm{O}$ at the plant surface.

\subsection{Upscaling of methane, $\mathrm{CH}_{4}$}

The discovery of aerobic $\mathrm{CH}_{4}$ emissions from plants became breaking news in 2006 (Kepler et al. 2006), mainly because their global upscaling suggested a source strength of 62-236 $\mathrm{Tg} \mathrm{yr}^{-1}$, which represented approximately $10-40 \%$ of the annual total of methane entering the modern atmosphere, and approximately $30-100 \%$ of annual methane entering the preindustrial ( 0 to $1700 \mathrm{AD}$ ) atmosphere (Ferretti et al. 2007). Four independent research groups subsequently revised the global magnitude of this potential $\mathrm{CH}_{4}$ source by different approaches, and jointly suggested emissions in the lower end compared to the pioneering study by Kepler et al. (2006). Based on carbon stable isotope analysis (Ferretti et al. 2007), standing leaf biomass (Parsons et al. 2006), leaf-mass-based estimation and photosynthesis-based estimation (Kirschbaum et al. 2006), and extrapolation from initially reported chamber measurements (Butenhoff and Khalil 2007), aerobic $\mathrm{CH}_{4}$ emissions from vegetation were respectively estimated at $0-176$ $\mathrm{Tg} \mathrm{yr}^{-1}, 42 \mathrm{Tg} \mathrm{yr}^{-1}, 10-60 \mathrm{Tg} \mathrm{yr}^{-1}$ and $20-69 \mathrm{Tg} \mathrm{yr}^{-1}$. None of the studies revealed underlying mechanisms for aerobic $\mathrm{CH}_{4}$ emission.

At the American Geophysical Union (AGU) fall meeting in 2007, three groups presented a major driving factor, UV-radiation, for the aerobic $\mathrm{CH}_{4}$ emission (Bruhn et al. 2007; Röckmann et al. 2007; Vigano et al. 2007), and in the following years UV generated $\mathrm{CH}_{4}$ emission was confirmed in several publications (Vigano et al. (2008, 2009); McLeod et al. 2008; Keppler et al. 2008; Bruhn et al 2009; Messenger et al. 2009). McLeod and Keppler (2010) concluded in a review that the proposed formation of $\mathrm{CH}_{4}$ under aerobic conditions in plants is robust, but the magnitude and significance for the global $\mathrm{CH}_{4}$ budget remained unresolved.

After the discovery of UV as a driving factor, only one group has tried to upscale aerobic plant generated $\mathrm{CH}_{4}$; Bloom et al. (2010) provided a putatively low global estimate of 0.2-1.0 $\mathrm{Tg} \mathrm{y}^{-1}$ plant-produced $\mathrm{CH}_{4}$. The upscaling was only based on UV-induced $\mathrm{CH}_{4}$ emission measured from purified pectin. Bloom et al. (2010) 
assumed that UV-induced $\mathrm{CH}_{4}$ emission measured in purified pectin is representative of UV-induced leaf $\mathrm{CH}_{4}$ emission when taking leaf pectin content into account. However, we believe that there is good evidence in the literature to indicate that this is not the case, since Vigano et al. (2008) for example showed that, at a certain UV irradiation, the $\mathrm{CH}_{4}$ emission by commercially purified pectin was ca. $80 \mathrm{ng} \mathrm{CH} 4 \mathrm{~g}^{-1} \mathrm{DW}$ $\mathrm{h}^{-1}$, whereas that of dried perennial ryegrass leaf was almost three-fold higher at ca. $200 \mathrm{ng} \mathrm{CH}_{4} \mathrm{~g}^{-1} \mathrm{DW} \mathrm{h}^{-1}$ - see Bruhn et al (2012) for further discussions. Therefore, the current upscaling by Bloom et al. (2010) must be seen as a preliminary attempt to evaluate global significance from the basis of limited information, and it is important to gain more knowledge for modelling of the UV driven $\mathrm{CH}_{4}$ from plants at a global level. We suggest that future modelling of the UV driven $\mathrm{CH}_{4}$ from plants must include data obtained under field conditions with respect to plant growth and development, and exposure to natural sunlight. Such data are currently not available, and therefore methane upscaling is not included in this review.

\subsection{Upscaling of carbon monoxide, $\mathrm{CO}$}

All natural terrestrial direct $\mathrm{CO}$ emissions, in the range of 50-200 $\mathrm{Tg} \mathrm{CO} \mathrm{yr}^{-1}$, have hitherto been ascribed by the IPCC $(1995,2001)$ to photo-induced CO emission by living plants (cf. Tarr et al. 1995). However, in studies on underlying photo-induced CO emission by living plants (Seiler and Giehl 1977; Seiler et al. 1978), which were incorporated into global CO budgets in the early IPCC assessment reports (IPCC 1995, 2001), the UV component of (sun)light was not considered (Bruhn et al. 2013). Therefore, we still await a proper global estimate of UV radiance induced CO emission by living vegetation. Bruhn et al. (2013) provides the first in situ measurements of ecosystem CO emission by living plants in response to natural solar UV irradiation. Importantly, Bruhn et al. (2013) find that in the studied natural grass field the photo-induced $\mathrm{CO}$ emission due to natural solar UV radiation is more than half of the value of that due to total solar spectrum at the Earth's surface. This may imply that the previous global estimate of photo-induced CO emission from living plants of 50-200 $\mathrm{Tg} \mathrm{CO} \mathrm{yr}^{-1}$ (cf. Tarr et al. 1995) should perhaps be doubled. Thus, future global budgets need to include CO emission caused by natural UV irradiance.

Here, we use the results from Bruhn et al. (2013), and estimate the global UV driven CO emissions. The upscaling is based on in situ ecosystem-atmosphere $\mathrm{CO}$ exchange measurements from natural vegetation and under ambient UV-B conditions in September and October of 2011 at DTU Ris $\varnothing$ campus $\left(55^{\circ} 41^{\prime} 12^{\prime \prime} \mathrm{N}\right.$, $12^{\circ} 05^{\prime} 52^{\prime \prime} \mathrm{E}$ ) in combination with laboratory experiments with artificial UV (Figure 5.1.). For materials and methods see Bruhn et al. (2013), and for the upscaling procedure, see appendices B and C. There is substantial geographical variation in source strength (Fig. 5.1), which is mostly caused by the geographical 
variation in surface UV radiation intensity, similar to the responsiveness of $\mathrm{N}_{2} \mathrm{O}$ (Fig. 5.2). The emission of $\mathrm{CO}$ in response to the UV-component of natural solar radiation was also evident at the ecosystem scale. When scaled to the global level, the UV-induced emission of CO by vegetation surfaces amounts up to $22 \mathrm{Tg}$ $\mathrm{yr}^{-1}$, which equals $11-44 \%$ of all the natural terrestrial living plant sources hitherto accounted for, which range between 50 and $200 \mathrm{Tg} \mathrm{CO} \mathrm{yr}^{-1}$ (IPCC, 1995, 2001; Tarr et al. 1995).
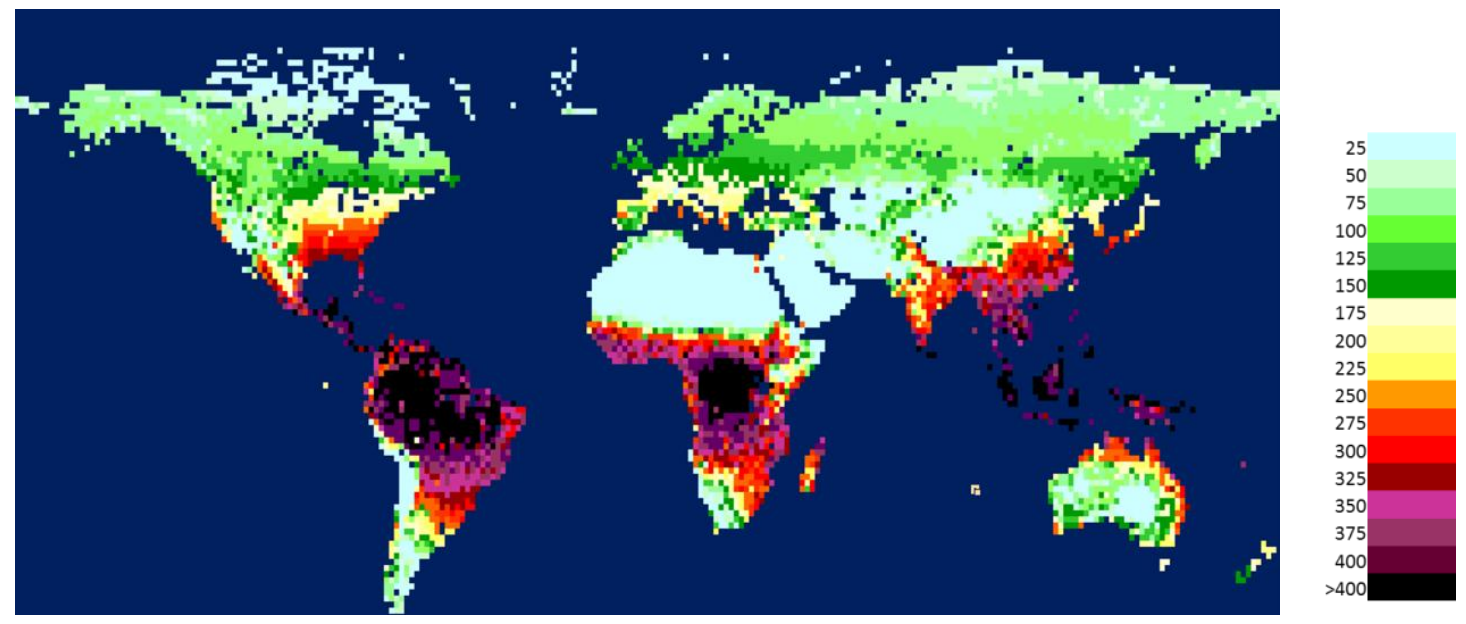

Figure. 5.1 Estimated annual global $\mathrm{CO}$ emissions $\left(\mathrm{mg} \mathrm{CO} \mathrm{m}^{-2}\right)$ from terrestrial vegetation surfaces induced by temperature and natural UV-radiation.

\subsection{Upscaling of Nitrous oxide, $\mathrm{N}_{2} \mathrm{O}$}

In order to evaluate the global significance of our new discovery of a terrestrial UV-driven $\mathrm{N}_{2} \mathrm{O}$ source, we attempted to scale the processes of temperature- and UV-induced $\mathrm{N}_{2} \mathrm{O}$ emission rates by vegetation to the global level (Fig. 5.2) - for materials and methods see Bruhn et al (2014) and upscaling procedure see appendices $B$ and $C$. The upscaling was feasible because the magnitude of measured $\mathrm{N}_{2} \mathrm{O}$ emission rates in response to natural sunlight, including low intensities of UV-radiation ranging from 280-400 nm, was similar to the magnitude of measured $\mathrm{N}_{2} \mathrm{O}$ emission rates in response to high intensities of artificial UV-radiation within the 309-314 nm narrow range (Bruhn et al. 2014b). The total of these radiation-driven $\mathrm{N}_{2} \mathrm{O}$ sources amounts to $0.65-0.78 \mathrm{Tg} \mathrm{yr}^{-1}$, which equals $7-24 \%$ of all the natural terrestrial $\mathrm{N}_{2} \mathrm{O}$ sources hitherto accounted for, which range between 3.3 and $9 \mathrm{Tg} \mathrm{N} \mathrm{yr}^{-1}$ (Solomon et al. 2007). There is substantial geographical variation in the source strength (Fig. 5.2), which is mostly caused by the geographical variation in surface UV radiation intensity - similar to the responsiveness of CO (Fig. 5.1). Importantly, the irradiance responses of $\mathrm{N}_{2} \mathrm{O}$ emissions across all examined wave length ranges (UV-B, UV-A, PAR) is steepest at low irradiance intensities (Bruhn et al. 2014b). This intensity-dependent sensitivity is not taken into account in 
our linear scaling of the UV-induced $\mathrm{N}_{2} \mathrm{O}$ emission rates to the global level, and it is therefore likely that we underestimate the $\mathrm{N}_{2} \mathrm{O}$ source strength.
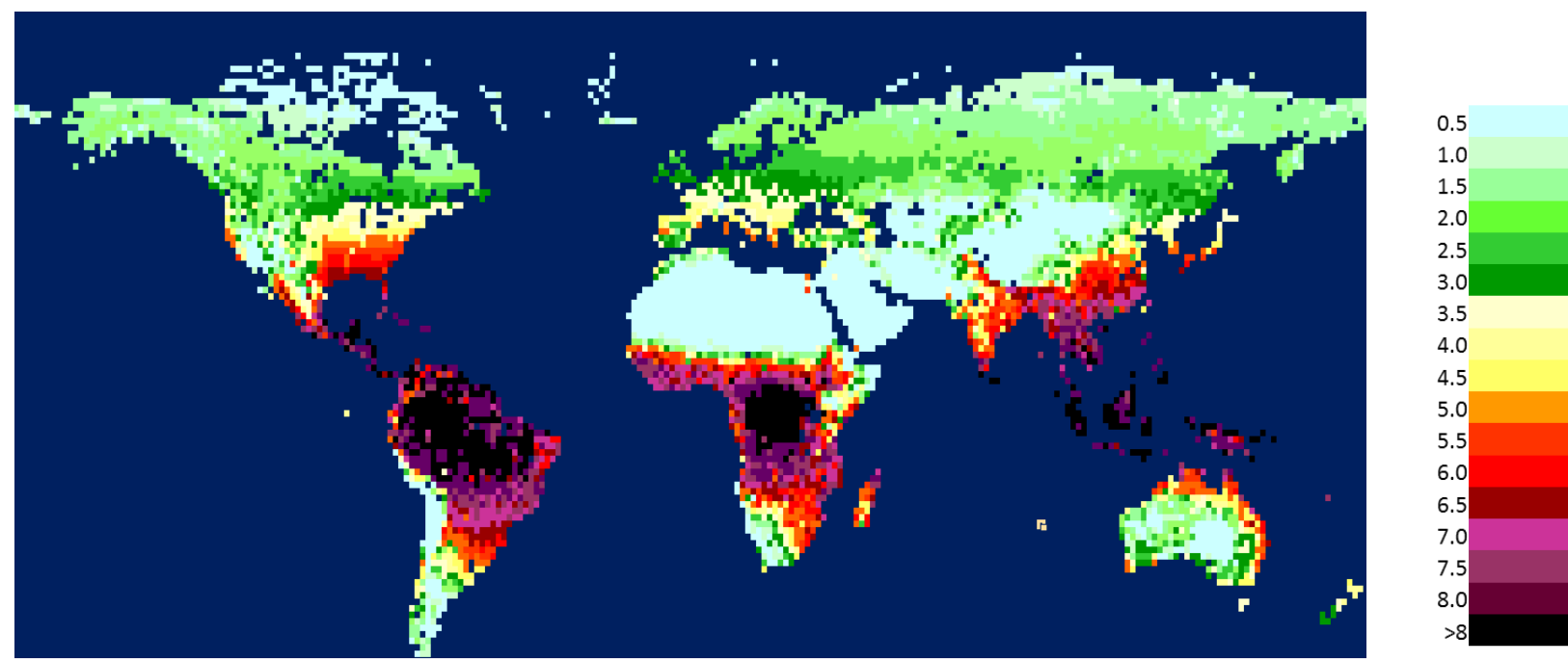

Figure 5.2. Estimated annual global $\mathrm{N}_{2} \mathrm{O}$ emissions $\left(\mathrm{mg} \mathrm{N}_{2} \mathrm{O} \mathrm{m}{ }^{-2}\right)$ from terrestrial vegetation surfaces, induced by temperature and natural UV-radiation.

\section{Perspectives and Conclusions}

\subsection{Realistic emission rates}

Despite the many reports on directly UV induced trace gas emission $\left(\mathrm{CH}_{4}, \mathrm{CO}, \mathrm{CO}_{2}, \mathrm{C2}-\mathrm{C} 5\right.$

hydrocarbons/NMVOC, $\mathrm{N}_{2} \mathrm{O}$ and $\mathrm{NO}_{x}$ ) from plant materials, there are very few studies with replicated measurements of plant trace gas emission in response to natural solar radiation including UV $\left(\mathrm{NO}_{y}\right.$, Raivonen et al. 2009; CO, Bruhn et al. 2013; $\mathrm{N}_{2} \mathrm{O}$, Bruhn et al. 2014b). In all three examples there were indications that measured realistic emission rates were substantial compared to those of other emission/uptake processes at the ecosystem level. At this stage it is unfortunately not possible to say anything in general about realistic emission rates from a wider perspective.

\subsection{Future studies}

From the evidence listed above it becomes apparent that much research is necessary for a more comprehensive understanding of mechanism, precursors and indeed in situ emission rates. Therefore we suggest that future experiments include tests of: 
- Action spectra and linearity in response function at low UV levels at intact tissues in many more species

- Responses to natural variation in UV intensities in the field

- Effect of deposition of especially N-precursors

- Direct responses to UV after the plants previously have been exposed to variable UV exposures during growth

- Investigation if stomatal conductance has any effects on the UV induced gas emission

\subsection{Known gas emission stimulated by UV}

It is well established that sunlight and UV in particular stimulate the production of several gases at the surface or near the surface of living plants. Currently there is documented evidence for production of the following gas species: $\mathrm{CH}_{4}, \mathrm{CO}, \mathrm{CO}_{2}, \mathrm{NMVOCs}, \mathrm{NO}_{x}$ and $\mathrm{N}_{2} \mathrm{O}$. The number of gases produced by UV stimulation is probably greater, but further gas screening studies are needed to assess this. Independent of gas species, the UV-induced gas emission rates documented until now are very low, and as a consequence it is very challenging with respect to equipment and experimental setup to investigate these processes. Most records concern $\mathrm{CH}_{4}$ production, but there are still many unanswered questions for this gas with regards to dose responses and production under natural conditions. For the other mentioned gases there are even more unanswered questions, nevertheless we have enough information to provide the first attempt at a global budget of UV-induced $\mathrm{CO}$ and $\mathrm{N}_{2} \mathrm{O}$ emissions based on measurements from natural vegetation under field conditions. The result indicates that UV driven CO production may contribute as much as $11-44 \%$ of all the natural terrestrial plant sources. The UV-induced $\mathrm{N}_{2} \mathrm{O}$ source equals $7-24 \%$ of the natural terrestrial source strength. These global estimates should be regarded as a contribution to an ongoing quantification process, but this high global share emphasizes the urgent need for more work. In order to establish reliable global estimates and enable future predictions, it is apparent that much research is necessary to elucidate mechanisms, precursors, environmental relationships and establishment of relevant and realistic emission rates.

\subsection{Perspectives}

This newly discovered light-associated aspect of trace gas emission from living vegetation may have significant consequences for our understanding of exchange processes between the global biosphere and atmosphere. It is very likely a global phenomenon occurring on all leaf surfaces exposed to sunlight in both 
managed and natural ecosystems. Our global estimates for $\mathrm{CO}$ and $\mathrm{N}_{2} \mathrm{O}$ under the current environmental conditions evidently show that radiation-driven processes are significant natural sources, and this could also be true for the other gases. An important feature is that the gas production is occurring at or just under the leaf surface, resulting in periodic high gas concentration within the boundary layer surrounding the leaves. This could for instance reduce the gas uptake of ozone in leaves since CO accelerates the reaction of $\mathrm{O}_{3}$ with ethylene (Horie and Moortgat, 1998), a process that has so far not been considered in ozone effect research. Through geological eras, the radiation-driven greenhouse gas (direct: $\mathrm{CO}_{2}, \mathrm{CH}_{4}, \mathrm{~N}_{2} \mathrm{O}$ and indirect: $\mathrm{CO}$ ) impact must have fluctuated with UV radiation and other processes producing or consuming greenhouse gases (e.g. soil respiration, denitrification and methanogens is in wetlands, and methane oxidation in upland soils), and therefore the development of climate on Earth.

Acknowledgements. We are thankful to Prof Ary Hoffmann for reading the manuscript and providing helpful suggestions for corrections and NordGen (The Nordic Genetic Resource Center) for providing seeds for the experiments. This work was supported by the FP7 EU Eclaire project.

\section{References}

Althoff $F$, Jugold A, Keppler F (2010) Methane formation by oxidation of ascorbic acid using iron minerals and hydrogen peroxide. Chemosphere 80: 286-292

Altimir N, Vesala T, Keronen P, Kulmala M Hari, P. (2002). Methodology for direct field measurements of ozone flux to foliage with shoot chambers. Atmospheric Environment 36(1): 19-29.

Aphalo PJ, Albert A, McLeod A, Heikkilä A, Gómez I, Figueroa FL, Robson TM, Strid Å (2012) Manipulating UV radiation. In: PJ Aphalo, A Albert, LO Björn, A McLeod, TM Robson, E Rosenqvist (eds.) Beyond the visible: A handbook of best practice in plant UV photobiology. COST Action FA0906 UV4growth. Helsinki, University of Helsinki, 176 pp.

Baur P, Stulle K, Schonherr J, Uhlig B (1998) Absorption of UV-B to blue light radiation by leaf cuticles of selected crop plants. Gartenbauwissenschaft 63: 145-152.

Beer C, Reichstein M, Tomelleri E, Ciais P, Jung M, Carvalhais N, Rödenbeck C, Arain MA, Baldocchi D, Bonan GB, Bondeau A, Cescatti A, Lasslop G, Lindroth A, Lomas M, Luyssaert S, Margolis H, Oleson KW, Roupsard O, Veenendaal E, Viovy N, Williams C, Woodward FI, Papale D (2010) Terrestrial gross carbon uptake: global distribution and covariation with climate. Science 329:834-838 
Björn LO (1996) Effects of ozone depletion and increased UV-B on terrestrial ecosystems, Int. J. Environ. Studies 51: 217-243.

Björn LO, McLeod A, Aphalo PJ, Albert A, Lindfors AV, Heikkilä A, Kolarž P, Ylianttila L, Zipoli G, Grifoni D, Huovinen P, Gómez I, Figueroa FL (2012). Quantifying UV radiation. In: PJ Aphalo, A Albert, LO Björn, A McLeod, TM Robson, E Rosenqvist (eds.) Beyond the visible: A handbook of best practice in plant UV photobiology. COST Action FA0906 UV4growth. Helsinki, University of Helsinki, 176 pp.

Bloom AA, Lee-Taylor J, Madronich S, Messinger DJ, Palmer PI, Reay DS, McLeod AR (2010) Global methane emission estimates from ultraviolet irradiation of terrestrial plant foliage. New Phytol 187: 417-425

Boucher O, Randall D, Artaxo P, Bretherton C, Feingold G, Forster P, Kerminen V-M, Kondo Y, Liao H, Lohmann U, Rasch P, Satheesh SK, Sherwood S, Stevens B and Zhang XY, 2013: Clouds and Aerosols. In: Climate Change 2013: The Physical Science Basis. Contribution of Working Group I to the Fifth Assessment Report of the Intergovernmental Panel on Climate Change [Stocker, TF, Qin D, Plattner G-K, Tignor M, Allen SK, Boschung J, Nauels A, Xia Y, Bex V and Midgley PM (eds.)]. Cambridge University Press, Cambridge, United Kingdom and New York, NY, USA.

Bowling DR, Miller JB, Rhodes ME, Burns SP, Monson RK, Baer D (2009). Soil, plant, and transport influences on methane in a subalpine forest under high ultraviolet irradiance. Biogeosciences 6: 1311-1324.

Brown MJ, Parker GG, Posner NE (1994) A survey of ultraviolet-B radiation in forests. Journal of Ecology 82: 843-854.

Bruhn D, Mikkelsen TN, Ambus P (2007) Aerobic Emission of Methane by Terrestrial Plant Material in Response to UV-irradiance. Eos Trans. AGU, 88(52), Fall Meet. Suppl., Abstract B53A-0940.

Bruhn D, Mikkelsen TN, Obro J, Willats WGT, Ambus P (2009). Effects of temperature, ultraviolet radiation and pectin methyl esterase on aerobic methane release from plant material. Plant Biol. 11: 43-48.

Bruhn D, Mikkelsen TN, Rolsted MMM, Egsgaard H, Ambus P (2014a) Leaf surface wax is a source of plant methane formation under UV radiation and in the presence of oxygen. Plant Biol. 16: 512-516.

Bruhn D, Moller IM, Mikkelsen TN, Ambus P (2012) Terrestrial plant methane production and emission. Physiol. Plant. 144: 201-209.

Bruhn D, Albert KR, Mikkelsen TN, Ambus P (2014b). UV-induced $\mathrm{N}_{2} \mathrm{O}$ emission from plants. Atmospheric Environment, 99: 206-214

Bruhn D, Albert KR, Mikkelsen TN, Ambus P (2013) UV-induced carbon monoxide emission from living vegetation. Biogeosciences, 10: 7877-7882 
581 Caldwell MM (1981) Plant response to solar ultraviolet-B radiation. P. 170-186. In Lange et al. (ed)

582 Physiological plant ecology. Springer-Verlag, Berlin.

583 Caldwell MM, Searles PS, Flint SD, Barnes PW (1999). Terrestrial ecosystem responses to solar UV-B 584 radiation mediated by vegeta-tion, microbes and abiotic chemistry, in: M.C. Press, J.D. Scholes, M.G. Barker 585 (Eds.), Physiological Plant Ecology, Blackwell Science, Oxford, 1999, pp. 241-262.

586 Caldwell MM, Teramura AH, Tevini M, Bornman JF, Bjorn LO, Kulandaivelu G (1995) Effects of increased 587 solar ultraviolet radiation on terrestrial plants. Ambio 24: 166-173.

588 Cen Y P and Bornman J F (1993) The effect of exposure to enhanced UV-B radiation on the penetration of 589 monochromatic and polychromatic UV-B radiation in leaves of Brassica-napus, Physiol. Plant., 87: 249-255.

590 Ciais P, Sabine C, Bala G, Bopp L, Brovkin V, Canadell J, Chhabra A, DeFries R, Galloway J, Heimann M, Jones 591 C, Le Quéré C, Myneni, Piao S, Thornton P (2013). Carbon and Other Biogeochemical Cycles. In: Climate 592 Change 2013: The Physical Science Basis. Contribution of Working Group I to the Fifth Assessment Report of 593 594 595 596 597 598 599 600 601 602 603 604 the Intergovernmental Panel on Climate Change [Stocker, TF, Qin D, Plattner G-K, Tignor M, Allen SK, Boschung J, Nauels A, Xia Y, Bex V and Midgley PM (eds.)]. Cambridge University Press, Cambridge, United Kingdom and New York, NY, USA.

Day TA, Zhang ET, Ruhland CT (2007) Effects of ultraviolet radiation accelerates mass and lignin loss of Larrea tridentate litter in the Sonoran Desert. Plant Ecol 193: 185-194.

Deckmyn GE, Cayenberghs E, Ceulemans (2001) UV-B and PAR in single and mixed canopies grown under different UV-B exclusions in field. Plant Ecol 154: 125-133.

Derendorp L, Holzinger R, Röckmann T, (2011b). UV-induced emissions of C2-C5 hydrocarbons from leaf litter. Environ. Chem. 8: 602-611.

Derendorp L, Quist JB, Holzinger R, Röckmann T (2011a) Emissions of $\mathrm{H}_{2}$ and CO from leaf litter of Sequoiadendron gigantum and their dependence on UV radiation and temperature. Atmos Environ 45: $7520-7524$.

605 Dueck T A, de Visser R, Poorter H, Persijn S, Gorissen A, de Visser W, Schapendonk A, Verhagen J, Snel J, 606 Harren FJM, Ngai AKY, Verstappen F, Bouwmeester H, Voesenek LACJ, van der Werf A (2007). No evidence 607 for substantial aerobic methane emission by terrestrial plants: ${ }^{13} \mathrm{C}$-labelling approach. New Phytologist 608 175: 29-35.

609 EPA (2010). Methane and Nitrous Oxide Emissions From Natural Sources. Office of Atmospheric Programs 610 (6207J), Washington, DC 20460, EPA 430-R-10-001.

611 Ferretti DF, Miller JB, White JWC, Lassey KR, Lowe DC, Etheridge DM (2007) Stable isotopes provide revised 612 global limits of aerobic methane emissions from plants. Atmospheric Chemistry and Physics 7: 237-241. 
613 Fraser WT, Blei E, Fry SC, Newman MF, Reay DS, Smith KA, Mcleod AR, 2015. Emission of methane, carbon 614 monoxide, carbon dioxide and short-chain hydrocarbons from vegetation foliage under ultraviolet 615 irradiation. Plant Cell Environ. 38: 980-989.

616 Grant RH (1997) Partitioning of biologically active radiation in plant canopies. Int J Biometeorol 40: 26-40.

617 Hari P, Raivonen M, Vesala T, Munger JW, Pilegaard K, Kulmala M (2003) Ultraviolet light and leaf emission 618 of $\mathrm{NO}_{x}$. Nature 422: 134.

619 Hartmann DL, Klein Tank AMG, Rusticucci M, Alexander LV, Brönnimann S, Charabi Y, Dentener FJ, 620 Dlugokencky EJ, Easterling DR, Kaplan A, Soden BJ, Thorne PW, Wild M, Zhai PM (2013). Observations: 621 Atmosphere and Surface. In: Climate Change 2013: The Physical Science Basis. Contribution of Working 622 Group I to the Fifth Assessment Report of the Intergovernmental Panel on Climate Change [Stocker, TF, Qin 623 D, Plattner G-K, Tignor M, Allen SK, Boschung J, Nauels A, Xia Y, Bex V and Midgley PM (eds.)]. Cambridge 624 University Press, Cambridge, United Kingdom and New York, NY, USA.

625 Horie O, Moortgat GK (1998) The effect of the addition of CO on the reaction of ozone with ethene. 626 Chemical Physics Letters, 288, 464-472. 
IPCC: Climate Change 2001: The Scientific Basis, Contribution of Working Group I to the Third Assessment Report of the Intergovernmental Panel on Climate Change, edited by: Houghton J T, Ding Y, Griggs D J, Noguer M, van der Linden P J, Dai X, Maskell K, Johnson C A. Cambridge University Press, Cambridge, United Kingdom and New York, NY, USA, 881 pp.

IPCC, 2013: Climate Change 2013: The Physical Science Basis. Contribution of Working Group I to the Fifth Assessment Report of the Intergovernmental Panel on Climate Change [Stocker, TF, Qin D, Plattner G-K, Tignor M, Allen SK, Boschung J, Nauels A, Xia Y, Bex V and Midgley PM (eds.)]. Cambridge University Press, Cambridge, United Kingdom and New York, NY, USA.

Isaksen I, Granier C, Myhre G, Berntsen T, Dalsren S, Gauss M, Klimont Z, Benestad R, Bousquet P, Collins W, Cox T, Eyring V, Fowler D, Fuzzi S, Jckel P, Laj P, Lohmann U, Maione M, Monks P, Prevot A, Raes F, Richter A, Rognerud B, Schulz M, Shindell D, Stevenson D, Storelvmo T, Wang WC, van Weele M, Wild M, Wuebbles D (2009) Atmospheric composition change: climate chemistry interactions. Atmos. Environ. 43: 5138-5192.

Jacobs JF, Koper GJM, Ursem WNJ (2007) UV protective coatings: a botanical approach, Prog. Org. Coat., 58: 166-171.

Karabourniotis G, Bornman JF (1999) Penetration of UV-A, UV-B and blue light though the leaf trichome layers of two xeromorphic plants, olive and oak, measured by optical fibre microprobes. Physiologia Plantarum 105: 655-661.

Keppler F, Boros M, Frankenberg C, Lelieveld J, McLeod A, Pirttila AM, Rockmann T, Schnitzler JP (2009) Methane formation in aerobic environments. Environ. Chem. 6: 459-465.

Keppler F, Hamilton JTG, Brass M, Rockmann T (2006). Methane emissions from terrestrial plants under aerobic conditions. Nature 439: 187-191.

Keppler F, Hamilton JTG, McRoberts WC, Vigano I, Brass M, Rockmann T (2008) Methoxyl groups of plant pectin as a precursor of atmospheric methane: evidence from deuterium labelling studies. New Phytol. 178: 808-814.

Khalil MAK and Rasmussen RA (1990) The global cycle of carbon monoxide: Trends and mass balance, Chemosphere, 20: 227-242.

Kim KH, Watanabe K, Menzel D, Freund H-J (2010) UV photo-dissociation and photodesorption of $\mathrm{N}_{2} \mathrm{O}$ on Ag(111). J. Phys. Condens. Matter 22: 084012. 
656 Kirschbaum MUF, Bruhn D, Etheridge DM, Evans JR, Farquhar GD, Gifford RM, Paul KI, Winters AJ (2006) A comment on the quantitative significance of aerobic methane release by plants. Functional Plant Biology 33: $521-530$.

659 660 661 662 663 664 665 666 667 668 669 670 671 672

Kirschbaum MUF, Niinemets Ü, Bruhn D, Winthers AJ (2007) How important is aerobic methane release by plants? Funct Plant Sci Biotech 1: 138-145

de Klein C, Harvey M (2015) Nitrous Oxide Chamber Methodology Guidelines. Version 1.1 ISBN 978-0-47840585-9 (online). Ministry for Primary Industries, Wellington 6140, New Zealand

Lee H, Rahn T, Throop HL, (2012) An accounting of C-based trace gas release during abiotic plant litter degradation. Global Change Biology 18: 1185-1195.

Liakoura V, Manetas Y, Karabouniotis G (2001) Seasonal fluctuations in the concentration of UV-absorbing compounds in leaves of some Mediterranean plants under field conditions. Physiologia Plantarum 111: 491-500.

Liakoura V, Bornmann JF, Karabourniotis G (2003) The ability of abaxial and adaxial epidermis of sun and shade leaves to attenuate UV-A and UV-B radiation in relation to the UV absorbing capacity of the whole leaf methanolic extracts, Physiol. Plant., 117: 33-43.

Long LM, Patel HP, Cory WC, Stapleton AE (2003) The maize epicuticular wax layer provides UV protection. Functional Plant Biology 30: 75-81.

Masson-Delmotte V, Schulz M, Abe-Ouchi A, Beer J, Ganopolski A, González Rouco JF, Jansen E, Lambeck K, Luterbacher J, Naish T, Osborn T, Otto-Bliesner B, Quinn T, Ramesh R, Rojas M, Shao X, Timmermann A (2013) Information from Paleoclimate Archives. In: Climate Change 2013: The Physical Science Basis. Contribution of Working Group I to the Fifth Assessment Report of the Intergovernmental Panel on Climate Change In: Climate Change 2013: The Physical Science Basis. Contribution of Working Group I to the Fifth Assessment Report of the Intergovernmental Panel on Climate Change [Stocker, TF, Qin D, Plattner G-K, Tignor M, Allen SK, Boschung J, Nauels A, Xia Y, Bex V and Midgley PM (eds.)]. Cambridge University Press, Cambridge, United Kingdom and New York, NY, USA.

McLeod AR, Fry SC, Loake GJ, Messenger DJ, Reay DS, Smith KA, Yun BW (2008). Ultraviolet radiation drives methane emissions from terrestrial plant pectins. New Phytol. 180: 124-132.

McLeod A, Keppler F (2010) Vegetation. In: Reay D, Smith P, van Amstel A (eds.) Methane and Climate Change. Earthscan, London and Washington, DC, pp 74-96. 
685

686

687

688

689

690

691

692

693

694

695

696

697

698

699

700

701

702

703

704

705

706

707

708

709

710

711

712

713

714

Messenger DJ, McLeod AR, Fry SC (2009) The role of ultraviolet radiation, phosensitizers, reactive oxygen species and ester groups in mechanisms of methane formation from pectin. Plant Cell Environ 32: 1-9

Mikkelsen TN, Bruhn D, Ambus P, Larsen KS, Ibrom A, Pilegaard K (2011) Is methane released from the forest canopy? Iforest-Biogeosci. For. 4: 200-204.

Mikkelsen TN, Ro-Poulsen H (2002) In situ autumn ozone fumigation of mature Norway spruce - effects on net photosynthesis. Phyton 42: 97-104.

Myhre G, Shindell D., Bréon F.-M., Collins W., Fuglestvedt J., Huang J., Koch D., Lamarque J.-F., Lee D., Mendoza B., Nakajima T., Robock A., Stephens G., Takemura T. and Zhang H., 2013: Anthropogenic and Natural Radiative Forcing. In: Climate Change 2013: The Physical Science Basis. Contribution of Working Group I to the Fifth Assessment Report of the Intergovernmental Panel on Climate Change [Stocker, TF, Qin D, Plattner G-K, Tignor M, Allen SK, Boschung J, Nauels A, Xia Y, Bex V and Midgley PM (eds.)]. Cambridge University Press, Cambridge, United Kingdom and New York, NY, USA.

Parsons AJ, Newton PCD, Clark H, Kelliher FM. 2006. Scaling methane emissions from vegetation. Trends in Ecology and Evolution 21: 423-424.

Potter C S, Klooster S A, Chatfield RB (1996) Consumption and production of carbon monoxide in soils: a global model analysis of spatial and seasonal variation, Chemosphere, 33: 1175-1193.

Prasad SS, Zipf EC (2008) Atmospheric production of nitrous oxide from excited ozone and its potentially important implications for global change studies. J. Geophys. Res. Atmos. 113: D15307.

Raivonen M, Bonn B, Sanz MJ, Vesala T, Kulmala M, Hari P (2006) UV-induced NOy emissions from Scots pine: could they originate from photolysis of deposited HNO3? Atmospheric Environment 40: 6201-6213. Raivonen M, Vesala T, Pirjola L, Altimir N, Keronen P, Kulmala M, Hari P (2009) Compensation point of $\mathrm{NO}_{x}$ exchange: Net result of $\mathrm{NO}_{x}$ consumption and production. Agricultural and Forest Meteorology 149: 10731081.

Rosenqvist E, Figueroa FL, Gómez I, Aphalo PJ (2012). Plant growing conditions. In: PJ Aphalo, A Albert, LO Björn, A McLeod, TM Robson, E Rosenqvist (eds.) Beyond the visible: A handbook of best practice in plant UV photobiology. COST Action FA0906 UV4growth. Helsinki, University of Helsinki, 176 pp.

Röckmann T, Vigano I, Holzinger R, van Weelden H, Keppler F (2007) News about methane emission from plant matter. Eos Trans. AGU, 88(52), Fall Meet. Suppl., Abstract B51F-05

Rozema J, van de Staaij J, Björn LO, Caldwell M (1997) UV-B as an environmental factor in plant life: stress and regulation, Trends Ecol. Evol. 12: 22-28. 
Rubasinghege G, Grassian VH (2009) Photochemistry of adsorbed nitrate on aluminum oxide particle surfaces. J. Phys. Chem. A 113: 7818-7825.

Rubasinghege G, Spak SN, Stainer CO, Carmichael GR, Grassian VH (2011) Abiotic mechanism for the formation of atmospheric nitrous oxide from ammonium nitrate. Environ. Sci. Technol. 45: 2691-2697. Schade GW, Hofmann R-F, Crutzen PJ (1999) CO emissions from degrading plant matter, (I) Measurements, Tellus B, 51: 889-908. 1999a.

Schade, GW, Crutzen PJ (1999): CO emissions from degrading plant matter (II), Estimate of a global source strength, Tellus B, 51: 909-918.

Shindell DT, Faluvegi G, Koch DM, Schmidt GA, Unger N, Bauer SE (2009) Improved attribution of climate forcing to emissions. Science, 326: 716-718.

Seiler W, Giehl H (1977) Influence of plants on the atmospheric carbon monoxide, Geophys. Res. Lett., 8: 329-332.

Seiler W, Giehl H, Bunse G (1978) The influence of plants on atmospheric carbon monoxide and dinitrogen oxide, Pure Appl. Geophys., 116: 439-451.

Shulski MD, Walter-Shea EA, Hubbard KG, Yuen GY, Horst G (2004) Penetration of photosynthetic active radiation and ultra violet radiation into Alfalfa and Tall Fescue canopies. Agronomy Journal 96: 1562-1571.

Smeets CJPP, Holzinger R, Vigano I, Goldstein AH, Rockmann T (2009) Eddy covariance methane measurements at a Ponderosa pine plantation in California. Atmos. Chem. Phys. 9: 8365-8375.

Solomon S, Qin D, Manning M, Chen Z, Marquis M, Averyt KB, Tignor M, Miller HL (eds.) (2007) Contribution of Working Group I to the Fourth Assessment Report of the Intergovernmental Panel on Climate Change, 2007, Cambridge Univ. Press.

Stocker TF, Qin D, Plattner G-K, Alexander LV, Allen SK, Bindoff NL, Bréon F-M, Church JA, Cubasch U, Emori S, Forster P, Friedlingstein P, Gillett N, Gregory JM, Hartmann DL, Jansen E, Kirtman B, Knutti R, Krishna Kumar K, Lemke P, Marotzke J, Masson-Delmotte V, Meehl GA, Mokhov II, Piao S, Ramaswamy V, Randall D, Rhein M, Rojas M, Sabine C, Shindell D, Talley LD,. Vaughan DG Xie S-P, 2013: Technical Summary. In: Climate Change 2013: The Physical Science Basis. Contribution of Working Group I to the Fifth Assessment Report of the Intergovernmental Panel on Climate Change [Stocker, TF, Qin D, Plattner G-K, Tignor M, Allen SK, Boschung J, Nauels A, Xia Y, Bex V and Midgley PM (eds.)]. Cambridge University Press, Cambridge, United Kingdom and New York, NY, USA. 
Sundqvist E, Crill P, Molder M, Vestin P Lindroth A (2012). "Atmospheric methane removal by boreal plants." Geophysical Research Letters 39: L21806.

Tarr M A, Miller W L, Zapp RG (1995) Direct carbon monoxide photoproduction from plant matter, J. Geophys. Res., 100: 11403-11413,

Tiiva P, Rinnan R, Faubert P, Rasanen J, Holopainen T, Kyro E and Holopainen JK (2007), Isoprene emission from a subarctic peatland under enhanced UV-B radiation, New Phytol. 176: 346-355.

Ueta I, Mizuguchi A, Tani K, Kawakubo S Saito Y (2013) Rapid Temperature-Programmed Separation of Carbon Monoxide and Carbon Dioxide on a Packed Capillary Column in Gas Chromatography: Application to the Evaluation of Photocatalytic Activity of $\mathrm{TiO}_{2}$. Analytical Sciences 29: 673-676.

Vigano I, Holzinger R \& Röckman T (2007) The isotope signature of methane emitted from plant matter upon irradiation with UV light. Eos Trans. AGU, 88(52), Fall Meet. Suppl., Abstract B53A-0938

Vigano I, van Weelden H, Holzinger R, Keepler F, Röckmann T (2008) Effect of UV radiation and temperature on the emission of methane from plant biomass and structural components. Biogeosciences 5: 937-947

Vigano I, Röckmann T, Holzinger R, van Dijk A, Keppler F, Greule M, Brand WA, Geilmann H, van Weelden H (2009). The stable isotope signature emitted from plant material under UV irradiation. Atmos Environ 43: 5637-5646.

Vigano I, van Weelden H, Holzinger R, Keppler F, McLeod A Röckmann T (2008). Effect of UV radiation and temperature on the emission of methane from plant biomass and structural components. Biogeosciences 5 : 937-947.

Yoshimura H, Zhu H, Wu Y, Ma R (2010) Spectral properties of plant leaves pertaining to urban landscape design of broad-spectrum solar ultraviolet radiation reduction. Int J Biometeorol 54: 179 - 191.

Worden HM, Deeter MN, Frankenberg C, George M, Nichitiu F, Worden J, Aben I, Bowman KW, Clerbaux C, Coheur PF, de Laat ATJ, Detweiler R, Drummond JR, Edwards D P, Gille JC, Hurtmans D, Luo M. MartínezAlonso S, Massie S, Pfister G, Warner JX (2013) Decadal record of satellite carbon monoxide observations, Atmos. Chem. Phys., 13: 837-850.

Yurganov L, McMillan W, Grechko E, Dzhola A (2010) Analysis of global and regional CO burdens measured from space between 2000 and 2009 and validated by ground-based solar tracking spectrometers. Atmos. Chem. Phys. 10: 3479-3494. 


\section{Appendix A}

\section{Methods \& techniques}

This appendix expands 3 methods \& techniques in the text with respect to environmental factors and other important issues related to measurements of UV induced gases.

\section{Temperature}

Particularly challenging is temperature control inside confinements made of transparent materials and at the same time exposed to intense irradiation by lamps or natural sunlight that may lead to severe scorching of plants. Under laboratory conditions, experiments may be run in well vented and temperature controlled growth cabinets (Bruhn et al. 2009) or enclosures equipped with heating tape (Vigano et al. 2008) to maintain stable temperature conditions. Direct temperature control of enclosures may include simple and inexpensive means such as ice blocks (M. Drösler, pers. comm.) or more advanced applications in the form of Peltier cooling technology (Mikkelsen and Ro-Poulsen, 2002; Bruhn et al. 2014; Sundqvist et al. 2012). Temperature can be determined directly at the leaf surface with a micro-thermocouple attached to the material (Keppler et al. 2006) or air temperature detected by thermocouples or conventional thermometers situated in the enclosure. Exterior surface temperature of enclosures can be measured by using a heat conducting steel probe connected to a high precision temperature meter (Bruhn et al. 2014).

\section{Chamber material}

Chambers should be made of materials that allow transmittance of UV-radiation without filtering. Commonly used materials in transparent chamber or plant cuvettes include UV-transparent synthetic quartz-glass, tradename Suprasil ${ }^{\circledR}$, that offers optimal UV-transmissions (Vigano et al. 2008; Rosenqvist et al. 2012; Bruhn et al. 2014), alternatively UV-transparent acrylic materials (Rosenqvist et al. 2012; Bruhn et al. 2014) can be used. Controlled transmittance of UV in experimental setups can be achieved by the application of filters to reduce or filter out specific UV-wavelengths reaching surfaces being investigated. Many commercial acrylic materials, with trade names such as e.g. Plexiglas or Perspex, will attenuate UV penetration and can be deployed to manipulate UV intensity (Bruhn et al. 2014). For specific and controlled filtering of UV radiation, various filters can be applied either at the light source or covering the enclosure windows; a comprehensive review of UV manipulation is given by Aphalo et al. (2012). 


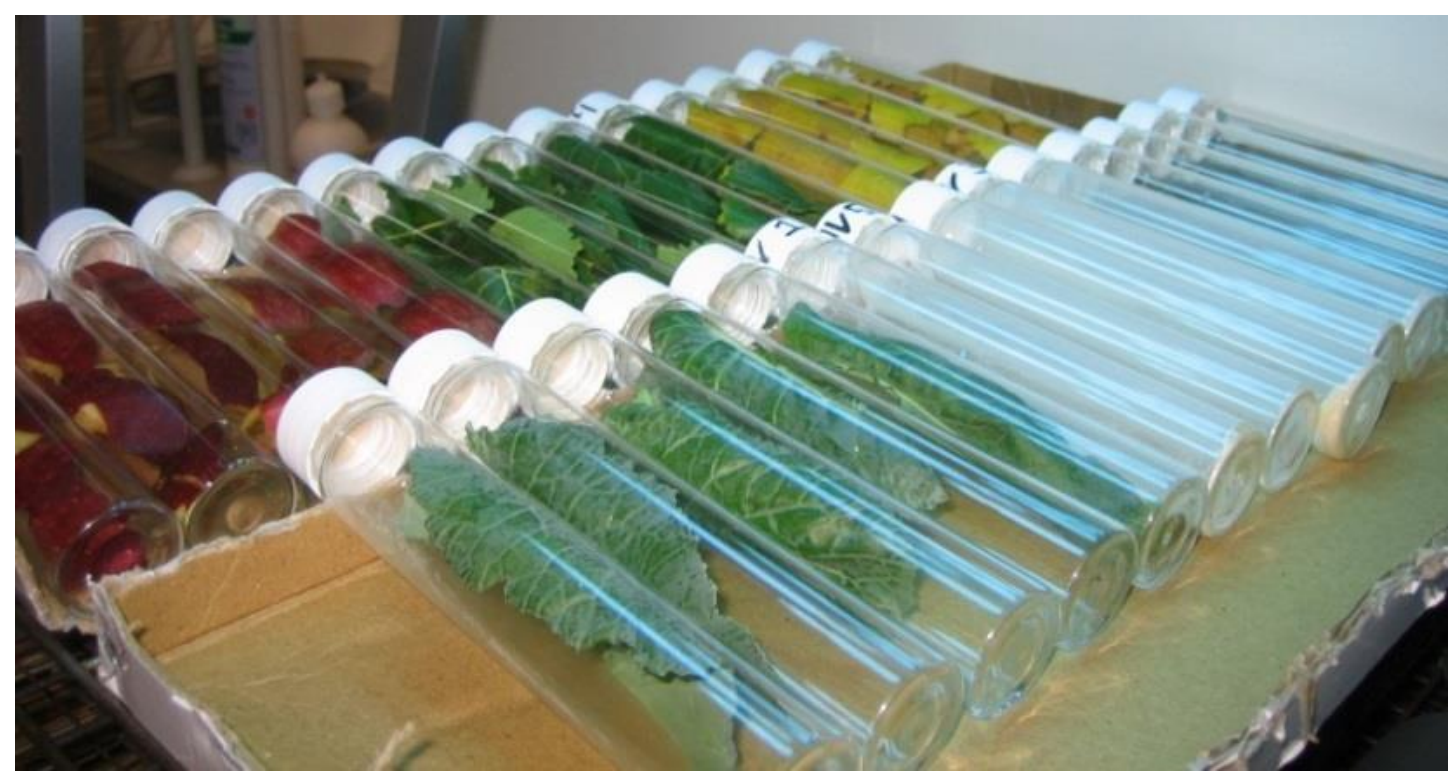

803 Figure A1. Plant leaves inserted in UV-B transparent vials. Note vials without leaves are used as blank controls.

\section{Surface reactions and reactive species}

Synthetic soft plastic and rubber materials used in growth cabinets such as hoses, tubes, pots, sealants and wire insulators, provide potential complications if exposed in experimental setups to study UV-induced gas emissions. Firstly, these materials may release phytotoxic compounds, leading to plant growth problems or plant death; for a review see Rosenqvist et al. (2012). Secondly, photochemical reactions on the surface of synthetic materials when exposed to UV-radiation can produce gases like methane (D. Bruhn, unpublished) or $\mathrm{N}_{2} \mathrm{O}$ (Bruhn et al. 2014) that may confound experimental results. For this reason, it is strongly recommended to include empty/blank controls in the experimental protocol (Bruhn et al. 2014; Sundqvist et al. 2012; Figure A1). Presence of synthetic materials in the experimental units should be minimized, and materials shielded with (e.g.) PFTE replaced with inert materials (glass, metal) where appropriate or preconditioned by heating (Sundqvist et al. 2012).

\section{Analysis of gas mixing ratios}

Analysis of mixing ratios of target gases in the enclosures can be achieved principally by two different approaches. These are $i$ ) manual grab sampling by syringe where a subsample of enclosure headspace is transferred to the analyzer or a storage vial for subsequent analysis; incubation may also take place in vials that can be mounted directly in the analytical unit such as a GC-autosampler, avoiding the need for manual sample transfer (Bruhn et al, 2014). Alternatively, ii) the headspace gas concentrations can be observed in 
real-time where the test unit is connected to an appropriate gas analyzer in a sealed gas loop for continuous or cyclic analysis (Sundqvist et al. 2012).

Gas-chromatography: Conventional GC-instrumentation equipped with Flame-lonization-Detection [FID] for $\mathrm{CH}_{4}$ (e.g. Vigano et al. 2008), methanizer-FID for $\mathrm{CO}$ and $\mathrm{CO}_{2}$ (Ueta et al. 2013) and Electron-CaptureDetection [ECD] for $\mathrm{N}_{2} \mathrm{O}$ (e.g. Bruhn et al. 2014) are applicable for grab sample analysis in order to crosscheck the optical techniques, and where experiments with small vials prevent measurements with optical systems that require additional sample volume. The reproducibility with GC-analysis is typically $\pm 10 \mathrm{ppb}$ although the micro-GC system tested by Ueta et al. (2013) for combined $\mathrm{CO}$ and $\mathrm{CO}_{2}$ analysis exhibited detection limits of 3 to $5 \mathrm{ppm}$. Trace-gas GC analysis at ambient concentrations require sample volumes of typically $0.5-1 \mathrm{ml}$.

Laser spectroscopy: During the last couple of decades laser spectrometers for sensitive, accurate and fast analysis of air trace gas constituents have become available at affordable pricing. In their work with UVinduced $\mathrm{CH}_{4}$ dynamics, Vigano et al. (2008) and Sundqvist et al. (2102) used an off-axis integrated cavity output spectrometer (Los Gatos Inc.) for real-time monitoring of $\mathrm{CH}_{4}$ mixing ratios. With use of laser spectroscopy, it is necessary to pay attention to cross-interference from other gas species; Vigano et al. (2008) verified this for plant emission of abundant methanol $\left(\mathrm{CH}_{3} \mathrm{OH}\right)$. For studies on UV-induced emissions of carbon monoxide (Bruhn et al. 2013) and nitrous oxide (Bruhn et al. 2014), a Los Gatos laser $\mathrm{N}_{2} \mathrm{O} / \mathrm{CO}$ spectrometer was applied following proper correction for cross-sensitivity with water and direct crossinterference between $\mathrm{CO}$ and $\mathrm{N}_{2} \mathrm{O}$. The sensitivity of laser spectrometers is several fold higher compared with GC analysis, and allows reproducibility in the range of $\pm 1 \mathrm{ppb}$.

Stable isotope analysis: GC combined with stable isotope (SI) analysis provides a powerful tool to study source partitioning and reaction pathways of trace gases emitted from surfaces. Isotope-ratio-massspectrometry (IRMS) in combination with proper pre-concentration (e.g. cryo-trapping) and chromatographic separation of analytical compounds has been used for studying carbon $\left({ }^{13} \mathrm{C}\right)$, hydrogen (deuterium; D) in $\mathrm{CH}_{4}$ (Keppler et al. 2006; 2008) and nitrogen $\left({ }^{15} \mathrm{~N}\right)$ in $\mathrm{N}_{2} \mathrm{O}$ (Bruhn et al. 2014). The reproducibility of gas mixing ratios by GC-IRMS is diminished ( $\pm 20-30 \mathrm{ppb}$ at ambient concentrations) compared with conventional GC analysis and the sample amount required for proper analysis is in the range of tens of milliliters. Dueck et al. (2007) analyzed the concentration of ${ }^{13} \mathrm{C}$-methane in $\mathrm{CH}_{4}$ emitted 
854 wave, optical parametric oscillator (OPO) and reported a detection limit of $3 \mathrm{ppb}$. Whereas the work by 855 Dueck et al. (2007) demonstrated only negligible emissions of $\mathrm{CH}_{4}$ based on the spectrometric method, 856 later work by Vigano et al. (2008) with the same plant material showed a contrasting result with significant emissions of ${ }^{13} \mathrm{C}_{-} \mathrm{CH}_{4}$, supposedly due to different analytical sensitivities (Vigano et al. 2008).

$858 \mathrm{SI}$ analysis encompasses recognition of the isotopic composition in gases emitted from materials with 859 isotopic abundances at natural levels (e.g. Keppler et al. 2006) as well as from isotopically enriched 860 materials (e.g. Bruhn et al. 2014). Isotopic variations arise from mass-dependent isotope fractionation in 861 biological and chemical processes, and natural abundance analysis of the trace gases, may add information 862 about the nature and origin of precursors. Application of the rare (heavy) isotope is valuable not only for 863 revealing information on specific precursor substances but also for providing a tool to study consumption 864 processes.

865 The recent development of isotopic laser spectrometers (e.g. instruments offered by Picarro, Aerodyne, Los 866 Gatos) provides new opportunities to investigate mechanisms and processes in UV-induced trace gas 867 emissions. However, so far no work taking advantage of these instruments has been reported in literature.

\section{Light sources}

869 Work on UV-induced trace gas emissions inevitably requires selection of a proper light source and establishment of associated irradiation intensities, wavelengths and action spectra. The selection of a light source is application driven and depends on the requirements imposed by the study. The main requirements concern the intensity and spectral distribution of radiant output of the lamp. The geometry 873 of the setup, including the source-target-distance and area of exposure, sets certain limits not only on the 874 light source but also on characteristics of the monochromator if this is applied (Aphalo et al. 2012).

875 In this context, it is important to stress that the current review addresses works investigating the direct 876 photolytic effect of UV-light exposure for plant-derived trace gas emissions. In this sense, translocation 877 studies where plants are grown under natural or controlled conditions with attenuated or enhanced UVexposure and subsequently examined for historical UV effects are not considered.

879 It is beyond the limits of this manuscript to present a detailed review and recommendation on selection of 880 proper light source equipment for UV studies. Instead, the reader is referred to comprehensive reviews on 881 usage of artificial light sources in UV photobiology given by Aphalo et al. (2012), and UV quantification 882 reviewed by Björn et al. (2012). A number of potential light sources can be selected for UV work, either as 
single light sources, or more often in combination to achieve desired optical conditions. A brief list is shown below; for a detailed discussion we refer to Aphalo et al. (2012).

Fluorescent lamps and tubes are low pressure mercury vapor lamps that emit radiation at specific spectral lines, mostly in the UV region of the spectrum

Xenon arc lamps are specialized light sources that produce intense visible and UV radiation. High intensity water-cooled deuterium lamps $(150 \mathrm{~W})$ have a fairly flat radiant intensity curve in the UV-B region that is appropriate for mechanistic plant UV photobiology studies.

Spectrographs composed of a light source and a monochromator may be used in applications requiring spectrally-resolved UV radiation exposure of biological specimens. Lasers usually produce very narrow and intense beams of monochromatic light. For the purpose of UV photobiology, tuneable optical parametric oscillator (OPO) pump lasers (pump wavelength $355 \mathrm{~nm}$ ) are especially useful.

Specific experimental setups for studying UV-effects on plant gas emissions are described in detail in literature cited above, and illustrate the complexity and experimental precautions associated with such studies. As an example, Vigano et al. (2008) used 6 types of lamps, one PAR lamp, four UV-A and UV-B lamps, and one UV-C lamp. The UV content (UV-A and UV-B separately) was determined with a Waldmann UV meter calibrated for each individual UV lamp, except for the UV-C lamp. These authors did not report on the action spectrum for $\mathrm{CH}_{4}$ release from biomass upon UV irradiation, and the UV strength was reported as the non-weighted integral over the UV-A range (400-320 nm), UV-B range (320-280 nm) or total UV range (400-280 nm). By choosing this approach (using unfiltered, non-weighted UV radiation) the authors neglected a possible wavelength dependence of the biologically effective dose (Vigano et al. 2008). Bruhn et al. (2009), in addition to PAR lamps, used four different lighting sources to obtain desired UV-B and UV-A irradiance; the UV sources were placed at varying distances to yield the reported irradiances. The irradiance spectra of the experimental tubes and the transmission spectra of the glass vials used were further established in order to reveal wavelength dependent responses in the experiments.

\section{Appendix B}

Global drivers for $\mathrm{CO}$ and $\mathrm{N}_{2} \mathrm{O}$ contribution 
Global $\mathrm{CO}$ and $\mathrm{N}_{2} \mathrm{O}$ up-scaling was based on the parameterized response equations to UV-irradiation and temperature (see Bruhn et al. 2013, 2014b; Appendix C).

The drivers were driven by geospatial satellite information on UV-B temperature and land surface classifications derived from normalized difference vegetation index (NDVI) and snow cover (SC). The UV310nm data was obtained from the Giovanni OMI/Aura Online Visualization and Analysis Daily Level 3 Global Gridded Products (http://giovanni.sci.gsfc.nasa.gov/giovanni/), the temperature data from MODIS (Moderate Resolution Imaging Spectroradiometer, NASA Earth Observations, http://neo.sci.gsfc.nasa.gov) and NDVI, LAI, and SC data from NASA Earth Observations (http://neo.sci.gsfc.nasa.gov/) and handled in a global longitude/latitude grid $(250 \times 150)$. The effect of UV was scaled with the global UV Irradiance at 310 $\mathrm{nm}$ at surface level (averaged across the years 2005, 2007, 2009, Local Noon Time). Temperature dependence was scaled based on daytime land surface temperatures averaged per month (over the ten years 2001-2010) of available data. The temperature response parameterization did not include temperatures below $0^{\circ} \mathrm{C}$, while the $\mathrm{CO} / \mathrm{N}_{2} \mathrm{O}$ emission from grids with a temperature below $0^{\circ} \mathrm{C}$ were set to zero in the up-scaling. Land surface area was determined from satellite land dataset information and the area was calculated from longitude/latitude information. Snow cover (SC) was averaged per month (2009) and we excluded areas covered by snow. The remaining land surface area was classified as being vegetation covered or vegetation free based on the NDVI. The up-scaling approach was conservative in the way that the surface area did not include topography. Further, most of the UV-radiation received by leaf surfaces are indeed screened (absorbed or reflected) by the surface wax (Cen and Bornman, 1993; Liakoura et al. 2003; Jacobs et al. 2007). Therefore, for the global estimate of the UV-effect on $\mathrm{CO} / \mathrm{N}_{2} \mathrm{O}$ emission by vegetation, we assumed an effective Leaf Area Index (LAI) of unity. The proportions of vegetation and sand area were determined by NDVI classification. Response functions for plants were applied to surface covered by vegetation. The NDVI were averaged per month (2009). Correlations between LAI satellite measurement and NDVI from 2009 showed that for instance NDVI around 0.3, 0.5, 0.7 and 0.75 reflects vegetation with $0.4,0.9,2.0$ and 4.0 layers of leaves per ground area (LAI) respectively (data not shown). This information was used to construct four groups with different distributions among vegetation and vegetation free surfaces. The groups are: (1) NDVI $<0.2,100 \%$ sand; (2) $0.2<N D V I<0.4,60 \%$ sand and $40 \%$ vegetation; 3 ) $0.4<\mathrm{NDVI}<0.6,20 \%$ sand and $80 \%$ vegetation; and (4) NDVI>0.6, $100 \%$ vegetation. These vegetation cover values are lower than a derivation from the NDVI LAI relationship would indicate, but since vegetation cover is clustered by nature with LAI values up to over 5 , this must result in more vegetation free areas than an average estimate would produce. For up-scaling, any LAI above 1 would give the same values. This division into group categories decides the percentage area of vegetation and vegetation-free combination in each of the $250 \times 150$ grid cells. 


\section{Appendix C}

946 Response functions for global CO and N2O contribution

947 For each of $250 \times 150$ grid cells (Appendix B) we estimated the $\mathrm{CO}$ or $\mathrm{N}_{2} \mathrm{O}$ emission rate $(E R$ ) on a monthly 948 basis as

$$
E R=\alpha \times e^{\beta \overline{T_{\text {day }}}} \times \frac{\overline{U V}}{50} \overline{\text { days } \times D L} \times \text { area } \times\left(1-\frac{\text { area }_{S C}}{\text { area }}\right) \times \text { prop }_{\text {cat }}
$$

949 where $\alpha$ is a base $E R$ of ecosystem CO or $\mathrm{N}_{2} \mathrm{O}$ emission $\left(\mathrm{nmol} \mathrm{m}^{-2} \mathrm{~h}^{-1}\right)$ measured at $21.4^{\circ} \mathrm{C}$ and $50 \mathrm{~mW}$ UV-B 950 (see Bruhn et al. 2013, 2014b). We assumed a response to temperature, $(T)=\alpha \times e^{\beta T}$, as measured at 951 leaf level (Bruhn et al. 2013, 2014b) when exposed to UV-B. In the up-scaling we substituted $T$ with a mean 952 daytime temperature for the respective grid cell, $\overline{T_{d a y}}$. As we have demonstrated near-linear relationships 953 between irradiance of both UV-B and UV-A and CO and N2O emissions, respectively (Bruhn et al. 2013, $9542014 \mathrm{~b}$ ), we scaled the base $E R$ of ecosystem $\mathrm{CO}$ or $\mathrm{N}_{2} \mathrm{O}$ emission with the mean UV Irradiance (mW) at 310 $955 \mathrm{~nm}$ at surface level for the grid cell. Further, ER for grid cell was adjusted according to the monthly average 956 day length per month, $\overline{D L}$, number of days per month, area and category of land vegetation. 